OPEN ACCESS

Edited by: Andreas Schwingshackl, University of California Los Angeles, USA

Reviewed by: Michael Shoykhet, Washington University

in St. Louis, USA

Vijay Srinivasan,

Children's Hospital of Philadelphia, USA

*Correspondence: Katri Typpo

ktyppo@email.arizona.edu

Specialty section:

This article was submitted to Pediatric Critical Care

a section of the journal

Frontiers in Pediatrics

Received: 21 June 2016 Accepted: 20 September 2016 Published: 13 October 2016

Citation:

Wilson B and Typpo K (2016) Nutrition: A Primary Therapy in Pediatric Acute Respiratory Distress Syndrome.

Front. Pediatr. 4:108. doi: 10.3389/fped.2016.00108

\section{Nutrition: A Primary Therapy in Pediatric Acute Respiratory Distress Syndrome}

\author{
Bryan Wilson ${ }^{1}$ and Katri Typpo ${ }^{2 *}$
}

${ }^{1}$ Department of Emergency Medicine, University of Arizona College of Medicine, Tucson, AZ, USA, ${ }^{2}$ Department of Pediatrics, Steele Children's Research Center, University of Arizona College of Medicine, Tucson, AZ, USA

Appropriate nutrition is an essential component of intensive care management of children with acute respiratory distress syndrome (ARDS) and is linked to patient outcomes. One out of every two children in the pediatric intensive care unit (PICU) will develop malnutrition or have worsening of baseline malnutrition and present with specific micronutrient deficiencies. Early and adequate enteral nutrition (EN) is associated with improved 60-day survival after pediatric critical illness, and, yet, despite early EN guidelines, critically ill children receive on average only 55\% of goal calories by PICU day 10. Inadequate delivery of EN is due to perceived feeding intolerance, reluctance to enterally feed children with hemodynamic instability, and fluid restriction. Underlying each of these factors is large practice variation between providers and across institutions for initiation, advancement, and maintenance of EN. Strategies to improve early initiation and advancement and to maintain delivery of EN are needed to improve morbidity and mortality from pediatric ARDS. Both, over and underfeeding, prolong duration of mechanical ventilation in children and worsen other organ function such that precise calorie goals are needed. The gut is thought to act as a "motor" of organ dysfunction, and emerging data regarding the role of intestinal barrier functions and the intestinal microbiome on organ dysfunction and outcomes of critical illness present exciting opportunities to improve patient outcomes. Nutrition should be considered a primary rather than supportive therapy for pediatric ARDS. Precise nutritional therapies, which are titrated and targeted to preservation of intestinal barrier function, prevention of intestinal dysbiosis, preservation of lean body mass, and blunting of the systemic inflammatory response, offer great potential for improving outcomes of pediatric ARDS. In this review, we examine the current evidence regarding dose, route, and timing of nutrition, current recommendations for provision of nutrition to children with ARDS, and the current literature for immune-modulating diets for pediatric ARDS. We will examine emerging data regarding the role of the intestinal microbiome in modulating the response to critical illness.

Keywords: pediatric, ARDS, nutrition, intensive care

\section{INTRODUCTION}

There are direct nutritive and non-nutritive benefits of feeding patients with pediatric acute respiratory distress syndrome (pARDS). Adequate nutrition therapy in support of protein, energy, and micronutrient needs prevents loss of lean body mass, improves protein turnover for production of acute phase and immune proteins, prevents depletion of tissue antioxidant systems which occur with 
starvation, and is associated with improved 60-day mortality in mechanically ventilated, critically ill children (1-3). Adequate protein delivery prevents loss of respiratory and cardiac muscle function and is associated with increased ventilator-free days and improved mortality in pARDS (4). And, yet, median delivery of enteral nutrition (EN) remains $40-75 \%$ of goal over the first week of pediatric intensive care unit (PICU) hospitalization $(3,5-10)$. In addition, as protein synthesis rates are reliant upon adequate protein delivery, patients may not realize benefits of adjuvant therapies that rely on protein signaling if they fail to meet goal EN.

The gastrointestinal tract is a primary lymphoid organ, housing $70 \%$ of all immune cells with the ability to alter systemic inflammatory responses (11-14). Non-nutritive benefits of feeding, therefore, include downstream reduction in pro-inflammatory signaling to the lung $(11,15,16)$. The gastrointestinal tract is an important target to improve lung inflammation, during pARDS, and subsequent patient outcomes. The intestinal epithelial barrier is a single-cell monolayer, which must absorb fluids and nutrients, interact with commensal organisms, and prevent entrance of pathogens and their toxic products (17). Intestinal barrier dysfunction has many downstream negative consequences. It is associated with bacterial translocation, endotoxemia, organ failure, immune dysfunction, and lung inflammation $(13,18,19)$. The intestinal epithelial barrier, the host microbiome, and intestinal immune system interaction contribute to the pathophysiology of pARDS and present novel therapeutic targets.
Specific nutrients provided at pharmacological doses or nutrition supplemented with immune-modulating factors may directly impact lung pro-inflammatory cytokines and neutrophil accumulation in the setting of pARDS (20-22). Non-nutritive goals of feeding with either a standard enteral formula or an immune-modulating formula include maintenance of intestinal barrier functions, to alter or attenuate the immune or inflammatory responses in pARDS, and to modulate microbiome and/or host-microbe interactions. The host microbiome is emerging as an important mediator in chronic as well as acute inflammatory states. An understanding of the necessary and sufficient nutrition for each of these nutritive and non-nutritive benefits is important to determine the minimum necessary macronutrient and micronutrient delivery during each phase of pARDS to optimize patient outcomes. Optimizing nutritional therapy to delivery the right nutrition to the right patient at the right time is an excellent opportunity to improve outcomes in pARDS.

\section{METABOLISM DURING PEDIATRIC CRITICAL ILLNESS}

Currently, knowledge of the normal nutritional needs of children and of the metabolic response to critical illness guides recommendations and goals for nutritional support in pediatric patients (Figure 1). Critical illness and the associated inflammation and tissue injury alter metabolism by inducing a catabolic state, which may exacerbate pre-existing malnutrition $(1,23)$. Metabolism

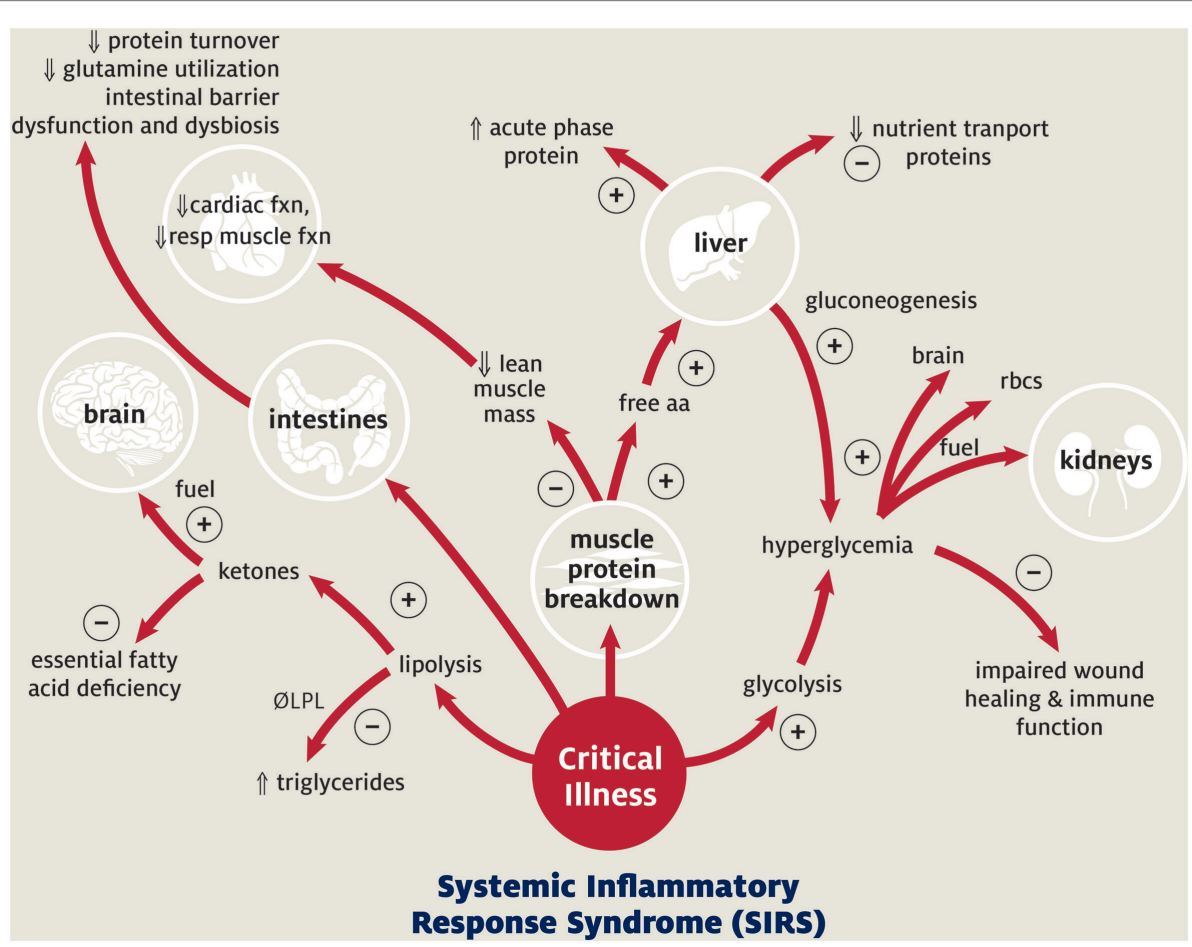

FIGURE 1 | Metabolic response to pediatric critical illness. + Acute adaptive response; - maladaptive consequence; $\boldsymbol{\uparrow}$ increased; $\boldsymbol{\downarrow}$ decreased. Abbreviations: LPL, lipoprotein lipase; aa, amino acids; resp, respiratory; rbc's, red blood cells. Adapted with permission from Graciano and Turner (25). Copyright from the Society of Critical Care Medicine. 
shifts away from growth to support the production of acute phase proteins, enzymes, and glucose to facilitate recovery $(23,24)$. This is accomplished through glycolysis, lipolysis, and protein turnover with resulting hyperglycemia, ketone production, and breakdown of skeletal muscle protein $(23,24)$. This diversion of resources results in cessation of normal growth and development in pediatric patients $(23,24)$. Prolonged persistence of this catabolic state progressively depletes the body's nutritional resources, ultimately leading to muscle wasting, impaired cardiopulmonary function, decreased immune response, and poor wound healing (Figure 1). Pediatric patients (especially those with pre-existing nutritional, cardiopulmonary, or muscular disease) are particularly susceptible to these adverse sequelae due to their limited macronutrient and micronutrient reserves. In the setting of pARDS, this loss of lean body mass and diaphragmatic function is likely to amplify the severity of the patient's respiratory failure and prolong ventilator dependence.

\section{PRE-EXISTING NUTRITIONAL STATUS MEDIATES PATIENT OUTCOMES}

Patients who are undernourished prior to their critical illness experience worse outcomes (Table 1) (26). High quality research to understand how adequacy of nutrition delivery and premorbid nutritional status influences outcomes of pARDS is limited; however, pre-illness nutritional status and adequacy of macronutrient delivery early in critical illness are well established as risk factors for morbidity and mortality of critically ill patients in neonatal and pediatric populations $(2,3,7,10,26-31)$. Malnutrition is both prevalent and incident in children hospitalized in the PICU; $30 \%$ of children admitted to the PICU have pre-existing acute or chronic malnutrition, and up to $58 \%$ of patients are discharged from the PICU malnourished $(3,6,28)$. Even children who are well nourished prior to their critical illness may develop acute protein-energy malnutrition within $48 \mathrm{~h}$ of PICU admission due to limited protein and energy reserves in the setting of severe acute illness (6, 32-35). In a study of 1622 mechanically ventilated children, underweight nutritional status based on admission BMI $z$-score was associated with an increase in hospital-acquired infections, fewer ventilator-free days, and lower likelihood of hospital discharge (Hazard ratio 0.71, $p<0.001$ ) (Table 1) (26). These high-risk patients may benefit from personalized nutritional strategies.

A growing percentage of children worldwide are now obese (39). While literature on the obese and critically ill pediatric patient is sparse, adult studies demonstrate a complex

TABLE 1 | Key observational studies of the impact of nutrition and nutritional status on patient outcomes in pediatric critical illness.

\begin{tabular}{lll}
\hline Study Patient population & $\begin{array}{l}\text { Exposure of Outcomes } \\
\text { interest }\end{array}$
\end{tabular}

Timing, dose, route nutrition

Wong Multicenter study of 107 children

et al. (4) with ARDS

Mikhailov Multicenter study of 5105 children

et al. (36) 1 month to 18 years with PICU

length of stay $\geq 96 \mathrm{~h}$

Mehta Multicenter study of 1245 children

et al. (2) 1 month to 18 years requiring mechanical ventilation $\geq 48 \mathrm{~h}$

Mehta Multicenter study of 500 children

et al. (3) 1 month to 18 years requiring mechanical ventilation $>48 \mathrm{~h}$

\section{Nutritional status}

$\begin{array}{ll}\text { Bechard } & \text { Multicenter study of } 1622 \\ \text { et al. (26) } & \text { mechanically ventilated children } \\ & \text { from } 2 \text { study cohorts } \\ \text { de Souza } & \text { Single-center prospective study } \\ \text { Menezes } & \text { of } 385 \text { critically ill children }\end{array}$

et al. (27) of 385 critically ill children

\section{EN safety and complications}

Lopez-Herce Single-center prospective, et al. (37) observational study of 526 critically ill children who received post-pyloric enteral nutrition (PEN)

Panchal Multicenter study of 339 children et al. (38) admitted to PICU for $\geq 96 \mathrm{~h}$ and on vasoactive infusions
Enteral calorie Reduction in ICU mortality in patients who received adequate calories (34.6 versus $60.5 \%$, and protein $\quad p=0.025$ ) and adequate protein (14.3 versus $60.2 \%, P=0.002$ ) compared with those who did adequacy not. Patients with adequate protein intake also had more VFDs [median (interquartile range), 12 (3.0-19.0) versus $0(0.0-14.8)$ days; $p=0.005]$

Early enteral Early EN was associated with lower odds of mortality (OR 0.52; 95\% Cl 0.34-0.76, $p=0.001)$. nutrition No significant differences in length of stay or duration of mechanical ventilation in patients exposed to early EN

Enteral protein Adequacy of enteral protein intake was associated with lower 60-day mortality $(p<0.001)$ adequacy adequacy

A higher percentage of goal energy intake via enteral nutrition route was significantly associated with lower 60 -day mortality $(p=0.002)$. Mortality was higher in patients who received PN $(p=0.008)$. Patients admitted to units that utilized a feeding protocol had a lower prevalence of acquired infections and this association was independent of the amount of energy or protein intake

Baseline $\quad$ BMl z-score classification as underweight or obese was associated with higher risk of hospitalnutritional acquired infections and lower likelihood of hospital discharge. Underweight children had a higher status risk of mortality and fewer ventilator-free days

Baseline Malnutrition (BMl $z$-score $<-2$ for weight for age, height for age, and BMl) was associated with nutritional greater length of mechanical ventilation and length of stay. Malnutrition was not a predictor of status mortality

Enteral The stepwise multivariate logistic regression analysis showed that the most important factors nutrition associated with gastrointestinal complications were shock, epinephrine at a rate higher than $0.3 \mu \mathrm{g} / \mathrm{kg} / \mathrm{min}$ and hypophosphatemia

Enteral Unadjusted mortality was lower in the patients exposed to EN (6.9 versus $15.9 \%, p<0.01)$. nutrition Vasoactive-inotropic score did not differ between the two groups except on day 1. No difference in gastrointestinal outcomes between patients who did and did not receive enteral nutrition

VFD, ventilator-free days; BMI, body mass index. 
relationship between obesity and clinical outcomes in critical illness and acute respiratory distress syndrome (ARDS) (40, 41). While overall morbidity, including ventilator days and length of hospitalization, is higher, mortality was lower $(40,41)$. A mortality benefit may be due to a higher nutritional reserve in the setting of prolonged catabolism $(40,41)$. Similar to risks in underweight children, obesity based on admission BMI $z$-score is associated with higher risk of hospital-acquired infections and lower likelihood of hospital discharge (hazard ratio 0.82, $p=0.04$ ) (26). It is important to note, however, that obesity is not exclusive of malnutrition and that the obese child should receive the same consideration for nutritional supplementation (40). Both obese and underweight children are at increased risk compared with normal weight children for adverse outcomes while undergoing mechanical ventilation (26). For this reason, a nutritional support strategy should include early screening and diagnosis of malnutrition (42).

\section{MACRONUTRIENT REQUIREMENTS DURING PEDIATRIC CRITICAL ILLNESS}

\section{Protein}

Protein requirements during acute illness are increased secondary to the catabolic state generated to support the production of acute phase proteins, repair of tissue, and the production of immune proteins (1). Protein demands can be increased by as much as $100 \%$ in severe sepsis, and even mild stressors, such as routine surgery, may increase protein needs by $25 \%$ (1). Infants who require extracorporeal membrane oxygenation have the highest reported rates of protein turnover in the literature (43, 44). As discussed previously, prolongation of this catabolic state can result in decreased cardiopulmonary function secondary to breakdown of cardiac and respiratory muscle mass. While evidence currently suggests this catabolic process is not averted through protein intake but prevents recruitment of lean muscle mass as the major source of amino acids and increases protein production (44), and muscle mass can be preserved (45). Many adjuvant therapies, such as insulin for treatment of stress hyperglycemia, may be dependent upon adequate protein delivery to demonstrate efficacy. In 12 neonates on extracorporeal membrane oxygenation, Agus et al. found that improved protein balance as a result of insulin therapy was only seen in patients with adequate protein delivery (44). Liebau et al. was able to improve protein balance, but not protein breakdown, in 10 critically ill adults with sufficient enteral protein delivery (46). Concurrent supplementation with adequate carbohydrate and lipid energy sources improves protein turnover and synthesis, thereby potentiating this counterbalancing (47). The decrease in protein breakdown seen with glucose supplementation in simple starvation does not decrease muscle catabolism for gluconeogenesis in the response to critical illness (47). Excessive protein administration should also be avoided as it can result in morbidity, such as azotemia, metabolic acidosis, and neurologic dysfunction, particularly as the patient improves and catabolic turnover subsides $(48,49)$. Recommended protein requirements in critically ill children vary by age and range from $3 \mathrm{~g} / \mathrm{kg} /$ day in infants to $1.5 \mathrm{~g} / \mathrm{kg} /$ day in adolescents (50).

\section{Energy}

Energy sources in the form of lipids and carbohydrates are needed to facilitate protein synthesis and meet the patient's total energy expenditure, which includes the energy needed for basal metabolism, growth, physical activity, and thermogenesis. Critical illness induces an unpredictable metabolic state in children, which makes calculation of energy requirements challenging (51-53). Decisions regarding energy prescription are further complicated by the inherent variability both between patients and within the same patient over the course of their ICU stay, depending on ICU course and severity of illness (54-57). Age, anthropometric criteria, biochemical criteria, clinical exam, disease category, and stage of illness have all been demonstrated to be poor predictors of energy expenditure $(51,54)$. Other common factors that affect total energy expenditure and further complicate estimation are fever, sedation, temperature support, paralytics, and ventilator support. The variation in these factors requires frequent reassessment and adjustment of nutritional support to accurately meet but not exceed the patient's nutritional requirements.

Given the inaccuracy of estimating energy requirements and negative consequences of both over and underfeeding patients, PICU nutritional guidelines currently endorse precise and personalized determination of energy needs by indirect calorimetry (50). The ongoing physical growth and cognitive development of children suggest a need for early and adequate nutrition, supported by evidence that even short episodes of starvation during infancy result in permanent neurocognitive losses $(29,58,59)$. One size does not fit most when it comes to delivery of calories and protein, and, in the absence of measured energy expenditure, patients may be easily misclassified as adequately fed when they are in fact over or underfed. This misclassification makes the relationship between energy adequacy and patient outcomes difficult to study. Indirect calorimetry is specifically recommended in the setting of outlier BMI ( $<5$ th percentile or $>85$ th percentile), a $>10 \%$ change in weight, prolonged ventilation, prolonged muscle relaxation, thermal injuries, oncologic diagnosis, or neurologic injury with dysautonomia (50). Indirect calorimetry is labor intensive, cannot be completed in all patients, and is poorly reimbursed but can be targeted to these high-risk populations, where precise nutritional support is likely to alter patient outcome (50). In the absence of measured resting energy expenditure, clinicians rely on predictive equations to assess calorie requirements and biomarkers to monitor for return of growth. Persistently elevated CRP and decreased prealbumin may indicate ongoing catabolism, while normalization may reflect transition to an anabolic state with a concurrent increase in energy requirements $(60,61)$.

Current recommendations are that energy should be prescribed as a balanced mixture of carbohydrates and lipids after appropriate provision of protein to preserve lean muscle mass (1). As previously discussed, the delivery of additional carbohydrates does not inhibit stress response gluconeogenesis and may result in hyperglycemia and its morbidities (poor wound healing, immune dysfunction, prolonged mechanical ventilation, and damage to the endothelial glycocalyx) (62-66). Lipid metabolism and turnover are increased in critical illness as fatty acids are used as a primary fuel source (64). Excessive carbohydrates are converted to lipids but generate carbon dioxide in the process, which may prolong 
mechanical ventilation (60). Infants and children generally have limited fat stores and are susceptible to the development of essential fatty acid deficiencies as early as 1 week into critical illness, if not receiving sufficient lipids. Lipids are generally limited to $30-40 \%$ of total calories. Balanced nutritional strategies provide sufficient macronutrients, while avoiding acute complications of excess protein, carbohydrate, and lipids.

\section{ADEQUATE ENTERAL NUTRITION IS ASSOCIATED WITH REDUCED MORTALITY IN PARDS}

\section{Evidence for Early Nutritional Support}

Prioritization of early EN is associated with improved tolerance of future EN and a reduction in morbidity from sepsis $(3,36)$. Murine studies demonstrated improved preservation of intestinal histoarchitecture and barrier function and improved local and remote organ immune function, with concurrent reduction in bacterial translocation and endotoxemia with the use of early EN (19, 67-70). Clinical research has demonstrated decreased mortality when EN is started within $48 \mathrm{~h}(30,36)$. Specifically, one large study of $>5000$ patients with a PICU stay $>96 \mathrm{~h}$ demonstrated a decrease in mortality associated with provision of at least $25 \%$ of goal calories within 48 h (Table 1) (36). Adult studies have examined starting EN within $6 \mathrm{~h}$ of ICU admission without complication (71). These lines of evidence support the preferential use of EN in pARDS when it is safe to do so, a recommendation supported by the 2015 Pediatric Acute Lung Injury Consensus Conference (72).

\section{Evidence for Dose of Enteral Nutrition}

Multiple retrospective studies demonstrate mortality benefit with improved adequacy of energy and protein provided during pediatric critical illness (Table 1) $(2,3,36)$. In a prospective, international study of nutritional practices in 500 children ventilated for $>48 \mathrm{~h}$, Mehta et al. found that patients who received less than $1 / 3$ of prescribed energy on average during the first 10 days after admission to the PICU had higher odds of mortality (3). An increase in prescribed energy by one tertile significantly decreased the odds of mortality. This relationship was only observed in patients with increased energy fed by the enteral route. ICUs, where a feeding guideline was in place, had overall lower hospital-acquired infection rates (3). Wong et al. examined 107 children with pARDS and identified that adequate energy and protein intake were associated with reduced mortality, while protein adequacy was also associated with increase ventilator-free days (4). These lines of evidence suggest that optimizing safe EN, rather than delivery of energy or protein via other routes of nutrition, is important for improving outcomes of pARDS.

Despite data regarding early nutritional adequacy and improved mortality, patients frequently fail to meet their calorie goals during the first week of illness with median intake generally falling at $40-75 \%$ due to multiple barriers to provision of $\mathrm{EN}(3,5-10)$. Mechanisms for poor patient outcome in the setting of under nutrition relate to both nutritive and non-nutritive sequelae of inadequate EN. Direct nutritive consequences to under nutrition are largely due to inadequate protein substrate for production of acute phase and immune proteins, with subsequent loss of lean body mass. This may lead to loss of both respiratory and cardiac muscle and difficulty with ventilator weaning (Figure 1). Non-nutritive benefits of EN include improved intestinal barrier function, improved immune function, and maintenance of intestinal microbiome diversity. Appropriate targets to monitor these non-nutritive benefits are under development. Therefore, "optimal" nutrition can be defined in many ways depending on the target to define efficacy: sufficient energy and protein to meet metabolic demand, sufficient energy and protein to maintain lean body mass and functional recovery, sufficient energy and protein to maintain neurocognitive development, sufficient EN to maintain intestinal barrier functions, and adequate enteral composition to maintain microbiome diversity. The appropriate nutritional target in children with ARDS is not defined.

\section{OVERFEEDING AND UNDERFEEDING ARE ASSOCIATED WITH WORSE OUTCOME IN PEDIATRIC CRITICAL ILLNESS}

Studies in adults and animals suggest negative impact of excessive nutrition with difficulty with ventilator weaning and either a mortality benefit or non-inferiority with restricted caloric intake (Table 2) (73-79). Several retrospective studies in critically ill children identify overfeeding occurring in PICU patients with negative clinical consequences $(53,80)$. Overfeeding is associated with delayed ventilator weaning, lipogenesis, hepatic dysfunction, hyperglycemia, increased mortality, and prolonged hospitalization. Complications associated with underfeeding included delayed ventilator weaning, impaired protein synthesis, organ failure, and an increased risk of sepsis $(7,10,24,32)$. Several potential mechanisms exist for the negative impact of overfeeding on patient outcome, such as increase in carbon dioxide production, increased intolerance of EN and parenteral nutrition (PN), refeeding syndrome, azotemia and metabolic acidosis from excess protein administration, hepatic steatosis from excess glucose delivery, hyperglycemia, hypertriglyceridemia, and on the cellular level the suppression of autophagy $(53,62,81,82)$. Administration of PN early in the course of critical illness may suppress autophagy, a necessary form of programmed cell death, which aids in removal of damaged proteins and mitochondria and is thought to play a role in recovery after organ failure (83).

\section{ADULT ICU GUIDELINES}

American Society of Parenteral and Enteral Nutrition (ASPEN) Guidelines of the Provision and Assessment of Nutrition Support Therapy in the Adult Critically Ill Patient recommend that patients with ALI/ARDS receive either trophic or full EN over the first week of hospitalization. Even in adults, there is uncertainty regarding timing and dose of nutrition therapy. Evidence exists that hypocaloric nutritional strategies, experienced by the majority of patients, may not benefit specific subsets of the critically ill, such as in the setting of mechanical ventilation, severe burns, and surgery (111-113). Patients at high nutritional risk, 
Dose, route, and timing

Parenteral nutrition

Fivez et al. (84)

Multicenter RCT involving 1440 critically ill children

Harvey et al. (85)

Multicenter RCT of 2400 critically ill adults

Doig et al. (86)

Multicenter RCT of 1372 critically ill adults

Heidegger et al. (87)

Multicenter RCT of 153 critically ill adults meeting $<60 \%$ of caloric needs by EN on ICU day 3

Casaer et al. (88)
$\mathrm{PN}$ at $24 \mathrm{~h}$ versus 1 week (EN initiated in both groups)

Early PN versus Early EN up to 5 days after ICU admission in adults who could be enterally fed

Early PN versus standard care for patients with relative contraindications to early EN

Supplemental PN versus EN alone on days 4-8

$\mathrm{PN}$ at $48 \mathrm{~h}$ versus 1 week (EN initiated in both groups)

Dose of macronutrients

Arabi et al. (89)

Multicenter RCT of 894 critically ill adults

Braunschweig

et al. (90)

Rice et al. (91)

Single-center RCT of 78 adults with acute lung injury

Multicenter RCT of 1000 adults with acute lung injury

Gastric versus post-pyloric feeds

Davies et al. (92) Multicenter RCT of 181 critically ill and

intubated adults with elevated gastric residuals

Acosta-Escribano et al. Single-center RCT of 104 adults with severe (93)

Hsu et al. (94) traumatic brain injury

Single-center RCT of 121 critically ill adults

Early enteral nutrition

Khorasani and

Mansouri (95)

Continuous versus bol

Single-center RCT of 688 burned children

MacLeod et al. (96)

Single-center prospective RCT of 164 critically

ill adult trauma patients

Glycemic control

NICE-SUGAR study

investigators et al. (9)
Multicenter RCT of 6104 critically ill adults
Permissive underfeeding of non-protein calories (40 to 60\% of goal) versus standard enteral feeding ( $75-100 \%$ of goal)

Intensive medical nutrition (>75\% goal) versus standard nutritional support ( $55 \%$ goal)

Early trophic versus full enteral feeding

Continuation of gastric feeds versus transition to post-pyloric

Gastric versus post-pyloric feeds

Gastric versus post-pyloric feeds

EN at 3-6 $h$ versus at $48 \mathrm{~h}$

EN as $q 4 h$ boluses versus continuous drip

Intensive glucose control (81-108 mg/dL) versus conventional contol $(<180 \mathrm{mg} / \mathrm{dL})$
No difference in mortality. Fewer infections in late PN (10.7 versus $18.5 \%)$ group, shorter duration of mechanical ventilation $(p=0.001)$, fewer patients required renal replacement therapy $(p=0.04)$, shorter ICU stays $(p=0.001)$

No difference in 30 - (33.1 versus $34.2 \%, p=0.57$ ) or 90 -day mortality $(p=0.4)$. Reduced hypoglycemia, vomiting in the early PN group. No difference in treated infectious complications

No difference in 60 -day mortality (21.5 versus $22.8 \%, p=0.6)$.

Early PN patients required fewer days of mechanical ventilation and experienced less muscle wasting

Supplemental PN associated with higher percentage of energy target and fewer nosocomial infections

No difference in mortality. Fewer ICU infections (22.8 versus $26.2 \%$, $p=0.008$ ) in late $\mathrm{PN}$ group, smaller proportion of patients with $>2$ days of mechanical ventilation, median reduction of 3 days for renal replacement therapy $(p=0.008)$

No difference in 90 -day mortality (27.2 versus $28.9 \%$, RR 0.94 ). No significant between-group differences for feeding intolerance, diarrhea, ICU-acquired infections, or length of stay

Significantly greater hospital mortality in intensive group (40 versus $16 \%, p=0.02)$

No difference in 28 -day ventilator-free days (14.9 versus 15.0 , $p=0.89$ ) or 60 -day mortality (23.2 versus $22.2 \%, p=0.77$ ). No differences in infectious complications between the groups. Initial trophic feeds were associated with less feeding intolerance

No clinically significant difference

Lower incidence of pneumonia in post-pyloric groups OR 0.3 (95\% C $0.1-0.7, p=0.01$ ) and higher percentage of nutrional needs met (92 versus $84 \%, p<0.01$ )

Post-pyloric feeds associated with earlier achievement of nutritional goals, less vomiting, and less pneumonia

Early EN associated with decreased length of stay and mortality (12 versus $8.5 \%, p<0.05$ )

Intermittent regimen reached goal quicker with no difference in complications

Higher mortality (OR 1.14; $95 \% \mathrm{Cl}, 1.02-1.28 ; p=0.02$ ) and more hypoglycemia (6.8 versus $0.5 \%, p<0.001$ ) in the intensive group 


\begin{tabular}{|c|c|c|c|}
\hline Study & Patient population & Intervention/comparison & Outcomes \\
\hline Vlasselaers 2009 (98) & $\begin{array}{l}\text { Single-center RCT of } 317 \text { critically ill infant and } \\
383 \text { critically ill children ( } 700 \text { total) }\end{array}$ & $\begin{array}{l}\text { Intensive normoglycemia with target glucose } 50-79 \text { (infant)/ } \\
70-100 \text { (children) versus target glucose }<214 \mathrm{mg} / \mathrm{dL}\end{array}$ & $\begin{array}{l}\text { Lower mortality ( } 3 \text { versus } 6 \%, p=0.013 \text { ) despite more hypoglycemia } \\
(25 \text { versus } 1 \%, p=0.001 \text { ) in the intensive group }\end{array}$ \\
\hline $\begin{array}{l}\text { Van den Berghe et al. } \\
\text { (99) }\end{array}$ & $\begin{array}{l}\text { Single-center RCT of } 1200 \text { critically ill adults } \\
\text { (medical) }\end{array}$ & $\begin{array}{l}\text { Intensive glucose control ( } 80-110 \mathrm{~g} / \mathrm{dL}) \text { versus conventional } \\
\text { control (<180 mg/dL) }\end{array}$ & $\begin{array}{l}\text { No difference in mortality but decreased acute kidney injury ( } 5.9 \\
\text { versus } 8.9 \%, p=0.04) \text {, earlier weaning from mechanical ventilation } \\
(p=0.03) \text {, and shorter hospital stay in intensive group }(p=0.05)\end{array}$ \\
\hline \multicolumn{4}{|l|}{ Immune modulation } \\
\hline \multicolumn{4}{|c|}{ Glutamine and selenium, antioxidants } \\
\hline Ziegler et al. (100) & Multicenter RCT of 150 critically ill adults & $\begin{array}{l}\text { Alanyl-glutamine dipeptide }(0.5 \mathrm{~g} / \mathrm{kg} / \mathrm{d}) \text { ), proportionally replacing } \\
\text { amino acids in PN versus standard PN (EN initated as tolerated) }\end{array}$ & No difference in clinical outcomes \\
\hline $\begin{array}{l}\text { Pérez-Bárcena et al. } \\
\text { (101) }\end{array}$ & $\begin{array}{l}\text { Multicenter RCT of } 142 \text { critically ill adults } \\
\text { (trauma) }\end{array}$ & $\begin{array}{l}\text { L-alanyl-L-glutamine dipeptide ( } 0.5 \mathrm{~g} / \mathrm{kg} \text { body weight/day) } \\
\text { supplementation for } 5 \text { days versus standard PN }\end{array}$ & No difference in clinical outcomes \\
\hline Heyland et al. (102) & Multicenter RCT of 1223 critically ill adults & $\begin{array}{l}\text { (L-alanyl-L-glutamine dipeptide at } 0.5 \mathrm{~g} / \mathrm{kg} \text { body weight/day } \\
\text { PN supplementation and } 42.5 \mathrm{~g} \text { of alanyl-glutamine and } \\
\text { glycine-glutamine dipeptides EN supplementation) versus } \\
\text { ( } 500 \mu \mathrm{g} \text { of selenium intravenously }+300 \mu \mathrm{g} \text { of selenium, } 20 \mathrm{mg} \text { of } \\
\text { zinc, } 10 \mathrm{mg} \text { of beta carotene, } 500 \mathrm{mg} \text { of vitamin } \mathrm{E} \text {, and } 1500 \mathrm{mg} \\
\text { of vitamin } \mathrm{C} \text { orally) versus combination versus placebo }\end{array}$ & $\begin{array}{l}\text { Higher mortality in those receiving glutamine (OR 1.28, Cl 1.00-1.64, } \\
p=0.05)\end{array}$ \\
\hline Carcillo et al. (103) & Multicenter RCT of 293 critically ill children & $\begin{array}{l}\text { Enteral zinc, selenium, glutamine and IV metoclopramide (ZSGM) } \\
\text { versus enteral WHEY protein and IV saline up to } 28 \text { days of ICU } \\
\text { stay }\end{array}$ & $\begin{array}{l}\text { No differences in time until first episode of nosocomial infection/ } \\
\text { sepsis (median WHEY } 13.2 \text { days versus ZSGM } 12.1 \text { days, } p=0.29 \text { ) } \\
\text { or the rate of nosocomial infection/sepsis ( } 4.83 / 100 \text { days WHEY } \\
\text { versus } 4.99 / 100 \text { days ZSGM, } p=0.81 \text { ) }\end{array}$ \\
\hline Andrews et al. (104) & Multicenter RCT of 502 critically ill adults & $\begin{array}{l}\text { Parenteral glutamine }(20.2 \mathrm{~g} / \text { day) or selenium }(500 \mu \mathrm{g} / \text { day }) \\
\text { or both for up to } 7 \text { days versus placebo }\end{array}$ & $\begin{array}{l}\text { No affect on new infections or mortality except for a reduction in } \\
\text { infections for patients receiving selenium for } 5 \text { or more days (OR } 0.53 \text {, } \\
\mathrm{Cl} \mathrm{0.30-0.93).}\end{array}$ \\
\hline Angstwurm et al. (105) & $\begin{array}{l}\text { Multicenter RCT of } 189 \text { adults with severe } \\
\text { sepsis/SIRS }\end{array}$ & $\begin{array}{l}\text { Selenium as } 1000 \mu \mathrm{g} \text { of sodium-selenite over } 30 \text { min followed by } \\
\text { continuous infusions of } 1000 \mu \mathrm{g} \text { daily for } 14 \text { days versus placebo }\end{array}$ & $\begin{array}{l}\text { Reduced mortality in the selenium group (OR } 0.56 ; \mathrm{Cl} 0.32-1.00 \text {, } \\
p=0.049 \text { ) }\end{array}$ \\
\hline \multicolumn{4}{|c|}{ Omega-3 fatty acids alone or in combination } \\
\hline $\begin{array}{l}\text { Grau-Carmona et al. } \\
\text { (106) }\end{array}$ & Multicenter RCT of 159 critically ill adults & $\begin{array}{l}\text { Total PN with a lipid emulsion containing } 10 \% \text { fish oil versus } \\
\text { a fish oil-free lipid emulsion }\end{array}$ & $\begin{array}{l}\text { Fish oil emulsion associated with decreased nosocomial infections } \\
(21.0 \text { versus } 37.2 \%, p=0.035)\end{array}$ \\
\hline Kagan et al. (107) & $\begin{array}{l}\text { Single-center RCT of } 120 \text { critically ill adults } \\
\text { (trauma) }\end{array}$ & $\begin{array}{l}\text { EN enriched with eicosapentaenoic acid, } \gamma \text {-linolenic acid, and } \\
\text { antioxidants versus a non-enriched control formula initiated at time } \\
\text { of admission }\end{array}$ & No significant difference in clinical outcomes \\
\hline van Zanten et al. (108) & Multicenter RCT of 301 intubated adults & $\begin{array}{l}\text { EN enriched with glutamine, omega-3 fatty acid, and antioxidants } \\
\text { (experimental product, NV Nutricia, Zoetermeer) versus high-protein } \\
\text { tube feed (Nutrison Advanced Protison, NV Nutricia, Zoetermeer) }\end{array}$ & $\begin{array}{l}\text { No difference in infection rate and increased } 6 \text {-month mortality } \\
\text { associated with immunomodulatory EN ( } 35 \text { versus } 54 \%, p=0.04 \text { ) }\end{array}$ \\
\hline Jacobs et al. (22) & $\begin{array}{l}\text { Multicenter RCT of } 26 \text { critically ill children with } \\
\text { acute lung injury }\end{array}$ & $\begin{array}{l}\text { EN supplemental with eicosapentaenoic acid, } \gamma \text {-linolenic acid, and } \\
\text { antioxidants versus standard EN }\end{array}$ & Improved biochemical profile \\
\hline $\begin{array}{l}\text { Pontes-Arruda et al. } \\
\text { (109) }\end{array}$ & Multicenter RCT of 115 critically ill adults & $\begin{array}{l}\text { Immunomodulator EN with eicosapentaenoic acid and } \gamma \text {-linolenic } \\
\text { acid (Oxepa) versus standard EN (Ensure Plus HN) }\end{array}$ & $\begin{array}{l}\text { No significant difference in mortality but immunomodulatory EN } \\
\text { associated with decreases in the severity of sepsis, cardiovascular } \\
\text { failure, respiratory failure, mechanical ventilation, and length of stay }\end{array}$ \\
\hline Radrizzani et al. (110) & Multicenter RCT of 326 critically ill adults & $\begin{array}{l}\text { Immunomodulatory EN (Perative, } 55 \% \text { carbohydrate, } 25 \% \text { fat, } \\
21 \% \text { protein, } 1.3 \mathrm{kcal} / \mathrm{mL} \text {, containing per } 100 \mathrm{~mL}: 0.8 \mathrm{~g} \text { L-arginine, } \\
0.15 \mathrm{~g} \omega-3 \text { fatty acids, } 0.7 \mathrm{~g} \omega-6 \text { fatty acids, } 2.9 \mathrm{mg} \text { vitamin } \mathrm{E} \text {, } \\
0.75 \mathrm{mg} \text {-carotene, } 2.2 \mathrm{mg} \text { zinc, and } 7 \mu \mathrm{g} \text { selenium) versus } \mathrm{PN} \\
\text { (containing } 59 \% \text { carbohydrate, } 23 \% \text { fat, } 18 \% \text { protein, } 1.2 \mathrm{kcal} / \mathrm{mL} \text { ) }\end{array}$ & $\begin{array}{l}\text { No difference in mortality. Immunomodulatory EN associated with } \\
\text { decreased progression to severe sepsis or septic shock (4.9 versus } \\
13.1 \%, p=0.022) \text { and shorter ICU length of stay }\end{array}$ \\
\hline
\end{tabular}


defined as either undernourished or overnourished at baseline may benefit from a more aggressive nutritional strategy (114). The intensive nutrition in acute lung injury (INTACT) study was designed to deliver $>75 \%$ of goal energy and protein needs daily to adult ICU patients via EN from date of diagnosis of ARDS to hospital discharge as compared with standard nutrition support (Table 2) (90). The INTACT study found increased mortality (40 versus $16 \%, p=0.02)$ with aggressive nutritional support $(85 \%$ of estimated energy expenditure) when compared with standard therapy (55\% of estimated energy expenditure) and was stopped early (90). While impossible to apply directly to pediatric patients due to their different metabolic needs and ongoing growth and neurocognitive development, these data reinforce the powerful role nutrition exerts on patient outcome and highlight the need for rigorous research to identify the optimal timing and dose of calories and protein, tailored to narrowly defined patient populations.

Individualized nutritional therapies that are "just right" and meet, but do not exceed, needs are currently recommended by ASPEN guidelines for nutritional prescription in critically ill children (50). "Optimal" energy and protein targets remain elusive, and response to nutrition delivery is likely related to baseline nutritional risk and current diagnosis. Increased utilization of non-invasive ventilation (NIV) in pARDS is associated with worse nutritional adequacy, and nutrition-related outcomes for patients managed with NIV are unknown (115). We do not know if potential benefits to NIV are outweighed by risks related to underfeeding. Underfeeding is harmful, but overfeeding is equally harmful. Multiple clinical trials are criticized for comparing very underfed to underfed patients, or for overfeeding patients. At the heart of these controversies lies the difficultly in determining in real-time calorie and protein needs and response to nutritional intervention. Advances in body composition assessments that are practical during pARDS in ultrasound, bioelectrical impedance, CT imaging, and functional outcomes assessments to monitor lean body mass close monitoring of lean body mass during pARDS a possibility, but require further study (116-119).

\section{ROUTE OF NUTRITION}

\section{Evidence for Gastric versus Post-pyloric Feeds}

The decision to prescribe gastric or post-pyloric EN has limited evidence to provide guidance. A study of 74 critically ill children randomly assigned to gastric or post-pyloric feeds demonstrated no difference in complications, and patients receiving postpyloric feeds received more of their prescribed calories (120). A large meta-analysis of adult patients with severe traumatic brain injury demonstrated a decreased risk of pneumonitis with post-pyloric feeds (121). Other researchers found an increased risk of gastrointestinal complications when post-pyloric feeds were used in septic patients or patients on epinephrine (Table 1) (37, 122). Institution-based policies regarding verification of enteral feeding tube position, particularly for post-pyloric feeds, may result in significant delays in initiation of feeds. No studies, so far, have specifically evaluated gastric versus post-pyloric feeds in the setting of pARDS.

\section{Evidence Regarding Parenteral Nutrition}

Current standard practice in the US is to reserve $\mathrm{PN}$ for situations in which EN fails or is not possible. This practice is rooted in retrospective evidence linking $\mathrm{PN}$ to increased risks of sepsis and mortality when compared with EN alone (3). Unfortunately, the evidence to guide clinical decisions is limited by current practice patterns. Because $\mathrm{PN}$ is reserved for the sicker patient who cannot tolerate $\mathrm{EN}$, retrospective studies are likely confounded by variables that predict both increased PN use and mortality. The Pediatric Early versus Late Parenteral Nutrition in Intensive Care Unit (PEPaNIC) study was an international, multicenter, randomized, and controlled trial comparing early versus late initiation of $\mathrm{PN}$ in critically ill children (Table 2) (123). The PEPaNIC Trial tested the relationship between early and later PN supplementation in 1440 children from newborn to 17 years of age and found no difference in mortality between the two groups (84). This study was not limited to children with pARDS. A significantly increased rate of hospital-acquired infections (18.5 versus $10.7 \%$ ) was present in patients in the early $\mathrm{PN}$ group as compared with the late PN group (84). However, characteristics of the study design limit the generalizability of this study to pARDS patients. The macronutrient dose was not controlled in the study, and central line utilization was not reported in experimental and control groups. The study patients were heterogeneous, and not exclusive to pARDS. Questions remain whether early PN is of benefit in pARDS. The potential benefit and/or harm from early PN is unclear, and the current clinical focus is to provide sufficient energy and protein preferentially by the enteral route until further studies are completed.

Research in neonatal intensive care unit supports the early use of at least low rates of EN to support bowel health in combination with PN to meet metabolic needs with the added advantage of fewer interruptions in nutrient delivery when $\mathrm{PN}$ is used (124). The use of this combination therapy, beginning with the first hours to days of life in preterm infants, has been associated with improved growth, improved neurodevelopment, improved EN tolerance, and decreased morbidity at both intermediate (18 months) and long-term (5 year) follow-up $(30,58,59,125)$. It remains unclear if older or term infants with ARDS might benefit from a similar early PN strategy with regard to short-term clinical and long-term neurocognitive outcomes. Research in the adult patient population have demonstrated mixed results with regard to days of mechanical ventilation and morbidity, such as infection and renal insufficiency $(78,86,88)$. This is consistent with previous literature suggesting improved outcomes with calorie restriction in the adult population (78). Given the ongoing growth and development of pediatric patients, it is reasonable to question whether combination therapy with EN and PN in children with pARDS will see similar benefits to those demonstrated in the NICU population. Despite the results of the PEPaNIC study, equipoise remains in the pARDS population. The optimal macronutrient dose, timing, and formulation of EN and PN support has yet to be elucidated as increasing evidence demonstrates 
links between the immune system, homeostasis, and nutritional intake (121, 126-129).

\section{Barriers to Nutritional Support}

Barriers to adequate EN can be broadly categorized as medical contraindication, prescriber discomfort, and frequent interruption $(7,9,130,131)$. Subjective rather than objective decisionmaking continues regarding decisions to initiate, advance, or maintain EN. Medical contraindications can include a need for volume restriction, hemodynamic instability, and ill-defined feeding intolerance. Studies in hemodynamically unstable adults requiring vasopressors demonstrated lower mortality with early EN (132). While large database studies do not demonstrate increase in adverse intestinal outcomes in children fed enterally while on vasoactive infusions, children with hemodynamic instability who do experience complications of EN have worse outcomes than children not fed by the enteral route $(38,122)$. Provider concerns regarding complications of EN in the setting of hemodynamic instability are warranted (122). Research is needed to further clarify the risks of EN while on vasoactive infusions, to identify optimal dosing strategies in the setting of hemodynamic instability, and to develop biomarkers to monitor safety of EN so that we might minimize risk, minimize unnecessary practice variation, and maximizing EN to patients at low risk of intestinal complications.

Feeding intolerance is the most frequent cause of interruption to EN, particularly in the current practice environment of deferring PN in marked preference for full EN. There is immense variability in clinician assessment of feeding intolerance and frequently used clinical criteria, such as bowel sounds, abdominal exam, gastric residual volumes, and lactate levels have not been validated $(9,130,133,134)$. Feeding intolerance occurs in $43-57 \%$ of critically ill children $(9,135)$. Even the definition of feeding intolerance is widely variable, and the natural history of bowel function in critical illness is yet to be fully elucidated (136, 137). Delayed gastric emptying and poor intestinal motility are causes of feeding intolerance, and, if left untreated, are impediments to achievement of goal EN. Delayed gastric emptying occurs in up to $50 \%$ percent of critically ill children, yet remains under recognized as a source of feeding intolerance (138). Promotility agents are commonly used for both gastric and intestinal dysmotility during pediatric critical illness, but only erythromycin and metoclopramide are currently approved in the US. Newer promotility agents, such as cholecystokinin receptor antagonists, ghrelin, and methylnaltrexone, in the setting of opioid-induced dysmotility, require further research in children with pARDS, but show promise to improve EN tolerance (138, 139). The development of validated tools for the diagnosis and monitoring of feeding intolerance represents an opportunity to significantly improve care in PICU patients by decreasing barriers to nutritional support. Biomarker-based guidelines for the initiation, advancement, and maintenance of EN are under development (140). Depending on hospital policies and local practice patterns, procedures are also a frequent cause of held EN and interruption of nutritional support despite an absence of data to guide these decisions (9). NIV and intensive therapies, such as extracorporeal membrane oxygenation, are in particular associated with nutritional interruption $(141,142)$. In adult ICU's, improved nutritional adequacy is reported when volume-based daily feeds are ordered, rather than an hourly rate (143). Volume-based orders accommodate 4-6 h of NPO status daily with the volume of EN delivered over 18-20 h, but larger studies are needed to understand the clinical outcome of a volume-based EN strategy in pARDS. A currently enrolling clinical trial, continuous versus bolus nasogastric feeding for mechanically ventilated pediatric patients (Clinical Trials ID: NCT02566070), will evaluate feeding intolerance and nutritional adequacy with two gastric feeding strategies. Consideration should be given to early initiation of a bowel regimen to prevent constipation and subsequent feeding intolerance while avoiding diarrhea and malabsorption. Implementation of an early EN guideline improved percent of goal energy and protein achieved in multiple retrospective studies, likely due to perceived emphasis on nutrition in a particular PICU $(144,145)$.

\section{Glycemic Control}

Literature in the adult population demonstrated compelling early evidence for significant decreases in morbidity and mortality with tight glycemic control (146). Subsequent research has demonstrated no benefit, but these results are drawn into question by large differences in mean glucose level and the use of point-of-care glucose testing rather than the arterial blood gas analysis used in the initial study (147-149). The negative impact of poor glycemic control is supported by current pediatric research, but the ideal target for blood glucose ranges has yet to be established $(98,150)$. The Heart And Lung Failure - Pediatric INsulin Titration (HALFPINT) trial (Clinical Trials ID: NCT01565941) is a multicenter, randomized clinical treatment trial comparing effectiveness of tight glycemic control to a target range of $80-110 \mathrm{mg} / \mathrm{dL}$ versus a target range of $150-180 \mathrm{mg} / \mathrm{dL}$.

\section{THE GUT AS THE MOTOR FOR ARDS}

There are many research opportunities to improve nutritional supplementation for critically ill patients in general as well as specifically within the framework of pARDS. Emerging research continues to demonstrate the role of gut dysfunction in the development of ARDS $(13,151)$. Deitch proposed the "gut lymph" hypothesis, whereby, the injured gut allows translocation of bacteria and bacterial products and liberates cytokines and chemokines, which act via the lymphatic duct to activate alveolar macrophages and contribute to pathogenesis of ARDS (152). Clark and Coopersmith proposed the "intestinal crosstalk" theory whereby the intestinal microbiota, immune system, and intestinal epithelial barrier interact and, when dysregulated, worsen systemic inflammation (153-155). Loss of balance in this "crosstalk" may lead to ARDS and is supported by emerging animal and human data examining the microbiome in critical illness. Modulation of intestinal barrier function and microbiome remain novel targets to improve outcomes in pARDS.

Several minimally invasive plasma biomarkers show promise in guiding initiation, titration, and continuation of EN by objectively assessing intestinal epithelial structure and function as 
well as assessing for the translocation of bacteria and bacterial products (Table 3) (156-158). The intestinal epithelial barrier is a single-cell monolayer tasked with competing roles to absorb nutrients, interact with commensal organisms, and limit entrance of pathogens and their products (Figure 2) (159, 160). It is the largest surface in the body in contact with the external environment. Intestinal barrier dysfunction is associated with the pathogenesis of multiple organ dysfunction, translocation of bacteria and endotoxin, and loss of remote organ immune function $(19,159,161)$. Enteral feeding of at least $15 \%$ of goal calories restores intestinal barrier function in murine models of critical illness (69). The minimum dose of EN required to maintain intestinal barrier function in children with pARDS is unknown. Biomarkers to monitor intestinal barrier function could guide provider decisions regarding the minimum necessary dose of enteral feeding. In a study of 20 children after cardiopulmonary bypass, biomarker concentrations were associated with symptoms of feeding intolerance (140). Biomarker-based decision rules for initiation, advancement, and maintenance of EN represent an opportunity to reduce practice variation and improve success in achieving and maintaining nutritional goals. The development of biomarkers to accurately and easily measure the catabolic and anabolic balance of the metabolic system is another area of ongoing research which will assist clinicians to more accurately develop nutritional prescriptions (46).

TABLE 3 | Minimally invasive plasma biomarker candidates to assess intestinal barrier function.

\begin{tabular}{|c|c|c|}
\hline Biomarker & Site specificity & Relevant data \\
\hline $\begin{array}{l}\text { Intestinal fatty } \\
\text { acid-binding } \\
\text { protein (I-FABP } \\
\text { or FABP2) }\end{array}$ & $\begin{array}{l}\text { Enterocytes of } \\
\text { the small and } \\
\text { large intestine }\end{array}$ & $\begin{array}{l}\text { Plasma concentration correlates with } \\
\text { histological phases of enterocyte injury } \\
\text { after ischemia-reperfusion and is a marker } \\
\text { of acute enterocyte damage }(156,157) \text {. } \\
\text { Predictive of poor outcome if elevated } \\
\text { after refeeding infants with NEC (158) }\end{array}$ \\
\hline $\begin{array}{l}\text { Liver fatty acid- } \\
\text { binding protein } \\
\text { (L-FABP) }\end{array}$ & $\begin{array}{l}\text { Enterocytes of } \\
\text { the small and } \\
\text { large intestine, } \\
\text { hepatocytes }\end{array}$ & $\begin{array}{l}\text { Plasma concentration discriminates } \\
\text { infants with sepsis versus NEC (162) }\end{array}$ \\
\hline Claudin 3 & $\begin{array}{l}\text { Apical tight } \\
\text { junction } \\
\text { complex }\end{array}$ & $\begin{array}{l}\text { Strong correlation between plasma } \\
\text { claudin } 3 \text { and enterocyte tight junction } \\
\text { loss in rat hemorrhagic shock model, } \\
\text { human necrotizing enterocolitis (163, 164). } \\
\text { Ubiquitous in lung tight junctions but lung } \\
\text { injury does not cause elevation in plasma } \\
\text { levels }\end{array}$ \\
\hline Citrulline & $\begin{array}{l}\text { Mature } \\
\text { enterocytes of } \\
\text { small intestine, } \\
\text { colon }\end{array}$ & $\begin{array}{l}\text { Manufactured in mitochondria of mature } \\
\text { enterocytes. Validated as a biomarker } \\
\text { for functional enterocyte mass in short } \\
\text { bowel syndrome, HIV patients, stem cell } \\
\text { transplant patients, graft-versus-host } \\
\text { disease, and in children after bowel } \\
\text { resection (165-171) }\end{array}$ \\
\hline Trefoil Factor 3 & $\begin{array}{l}\text { Intestinal goblet } \\
\text { and mucin cells }\end{array}$ & $\begin{array}{l}\text { Differentiates between surgical and } \\
\text { non-surgical NEC in preterm infants and } \\
\text { assess disease activity in inflammatory } \\
\text { bowel disease }(162,172)\end{array}$ \\
\hline
\end{tabular}

NEC, necrotizing enterocolitis; HIV, human immunodeficiency virus.

\section{INTESTINAL MICROBIOME MAY SHAPE IMMUNE RESPONSES}

Technological advances in computing power and analytic techniques over the last decade make the study of the human microbiome possible (173). In the human body, bacterial cells exceed human cells in number and perform many essential functions, such as production of short chain fatty acids and vitamins (vitamin K), which aid the human host (174). The developmental maturation of the human microbiome is poorly understood, but it reaches adult patterns by 2-4 years of age (175). Dysbiosis occurs when the symbiotic relationship between human and microbial populations is disturbed and may result in reduced microbiome diversity. Reduced microbiome diversity during infancy, a critical time period during microbiome development, may have lasting consequences on the development of several chronic diseases (176). Murine models where antibiotics are provided during infancy, demonstrate rapid and permanent alteration of metabolic phenotype via transient reduction in intestinal microbiome diversity (176-178). In contrast, an increased microbiome diversity in human infants enhances maturation of the intestinal mucosal immune system, which can influence LPS responsiveness at 1 year of age in humans (179). Thus, normal metabolic and immune imprinting by essential "keystone" microbes, which can be altered by early antibiotic exposures, may have long-term consequences on immune response to critical illness and risk of chronic illness. This emerging field has the potential to shift our targets with regard to control of both acute and chronic inflammation from modulation of human cells to modulation of the bacterial within us. The gastrointestinal microbiota is implicated in control of inflammation in the lung (180). Diet is a potent determinant of intestinal microbiome diversity and, in murine models, trumps genetic background (181). Carmody et al., demonstrated, in a murine model, that rapid changes in diet resulted in rapid shifts in microbial composition (181). As diet is an essential determinant of microbiome diversity and alters lung inflammation, dietary manipulation of the gastrointestinal microbiome may be a new target for treatment of pARDS. We do not know how medical diets alter the intestinal microbiome during pARDS, nor do we understand the short or long-term consequences of nutritional, probiotic, or pre-biotic interventions.

\section{IMMUNONUTRITION}

Immunonutrition is well tolerated and results in improved pro-inflammatory cytokine profiles, but is not associated with clear clinical outcome benefits (182). While small single-center studies of isolated pharmaconutrients showed promise, multiple combination nutritional and pharmacologic additives in critically ill adults aimed at modulating the inflammatory and immune response have not shown benefits (Table 2) $(183,184)$. Specific supplements that have been explored include several antioxidants, arginine, glutamine, metoclopramide, $\omega-3$ fatty acids, zinc, and selenium $(103,185-190)$. The randomized comparative effectiveness pediatric critical illness stress-induced immune suppression (CRISIS) prevention trial examined the effect in critically ill children of daily enteral zinc, selenium, glutamine, 


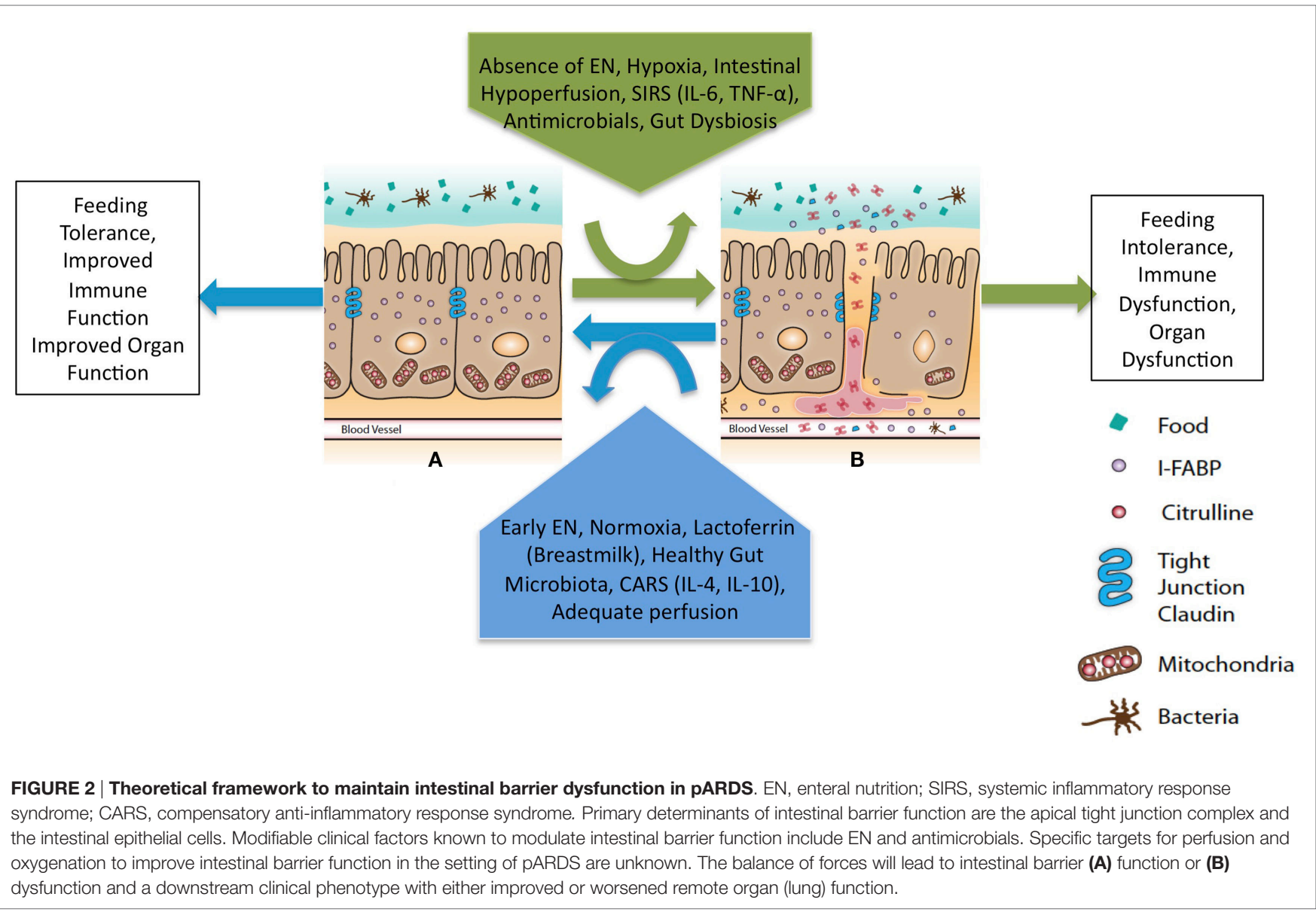

and IV metoclopramide on incidence of nosocomial infections. No difference was seen between the two groups, and the trial was stopped early due to futility (103). Multiple combination nutritional and pharmacologic additives in critically ill adults aimed at modulating the inflammatory and immune response have been trialed, but have generally not shown any benefits $(50,191)$. The optimal formulation of lipids is an area of active research with continued focus on the role of $\omega-3$ polyunsaturated fatty acids (PUFAs).

\section{OMEGA-3 POLYUNSATURATED FATTY ACIDS}

The use of $\omega-3$ PUFAs as a nutritional adjuvant have evidence suggesting they may reduce the pro-inflammatory state in ARDS, but a recent systematic review and meta-analysis looking specifically at ARDS patients in the adult ICU found no benefit in clinical outcomes $(107,192-197)$. The rationale for $\omega$-3 PUFAs is that they may be beneficial in ARDS as they would compete with $\omega-6$ PUFAs, decrease the synthesis of pro-inflammatory eicosanoids, increase production of anti-inflammatory lipid mediators, such as resolvins and protectins, decrease in chemotaxis, decrease reactive oxygen species (ROS) and pro-inflammatory cytokines, and decrease leukocyte binding and activation through decreased expression of adhesion molecules (Figure 3) (192).
Jacobs et al. evaluated the feasibility of $\omega$-3 PUFAs (eicosapentaenoic acid $+\gamma$-linolenic acid) in children with ALI and ARDS and examined the impact of $\omega$-3 PUFAs on plasma phospholipid fatty acid concentrations (22). They found that delivery of nutrition enriched with eicosapentaenoic acid $+\gamma$-linolenic acid was feasible and resulted in an anti-inflammatory fatty acid profile (22). This study is supportive of future work in this area in children. Whether a change in anti-inflammatory fatty acid profile will improve clinical outcomes is unclear, but promising. Methodological challenges in several adult trials limit conclusions regarding $\omega-3$ PUFAs in adult patients with ARDS (192). Specifically, studies are heterogeneous, and, in some, the control diet was pro-inflammatory.

Several $\omega-3$ PUFA-derived mediators are potential targets to resolve the inflammatory response in the setting of pARDS (Figure 3). Alveolar edema and neutrophil recruitment and activation are early events in ARDS. Resolvins, protectins, and maresins are lipid-derived mediators, and several resolvins are emerging as potential therapeutic targets for resolution of ARDS (Figure 3) $(20,21)$. These resolvins are derived from the $\omega-3$ PUFAs docosahexaenoic acid (DHA) and eicosapentaenoic acid (EPA). Eickmeier et al. found that aspirin-triggered resolvin D1 reduces mucosal inflammation and promotes resolution in a murine model of acute lung injury (21). Aspirin-triggered RV D1 decreased lung inflammation and promoted acute lung injury 


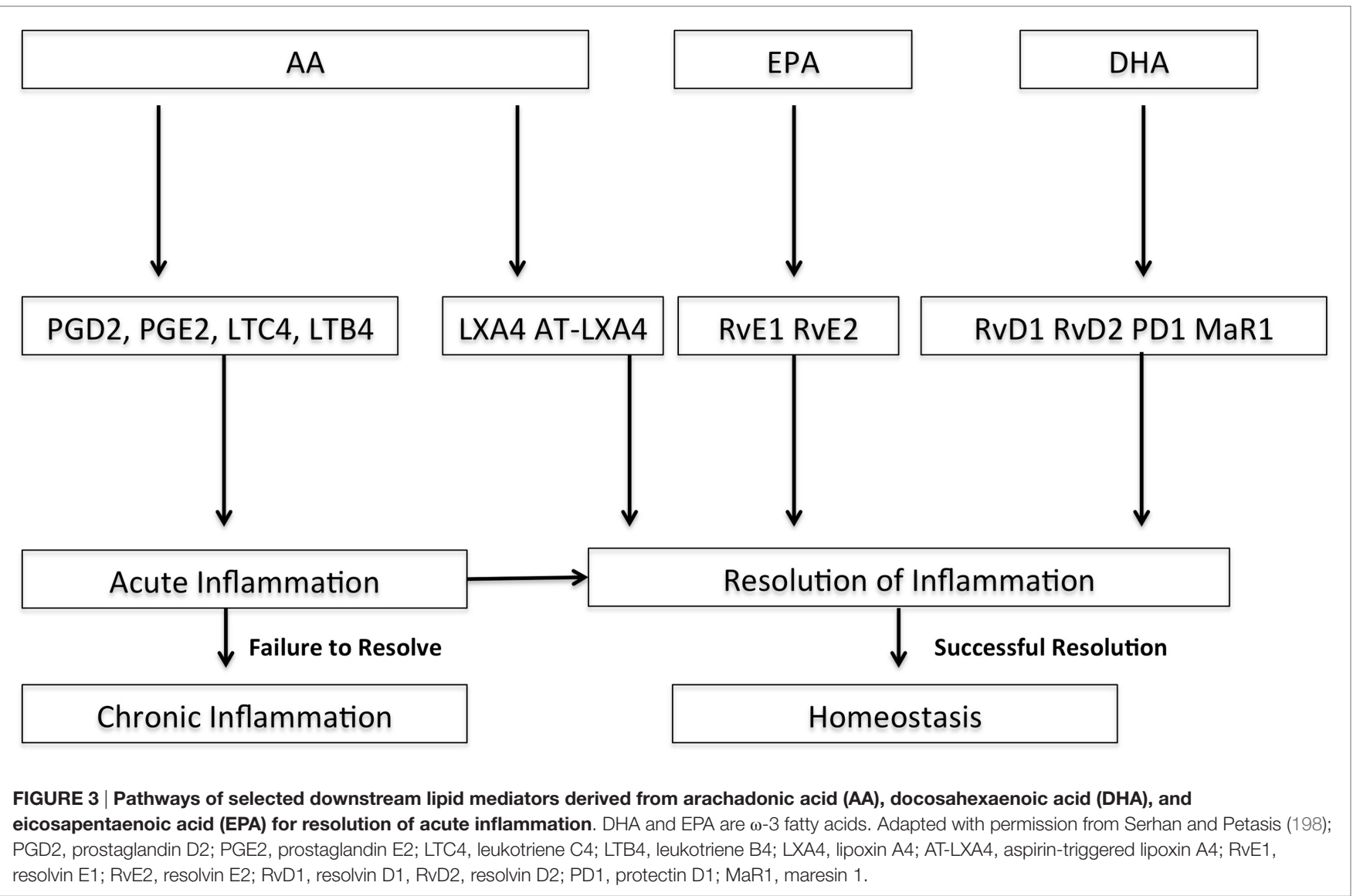

resolution shortly after injury in an hydrochloric acid model of ARDS by enhancing restitution of barrier integrity, decreasing circulating neutrophil-platelet heterotopic interactions, and regulating inflammatory mediators and nuclear factor- $\kappa \mathrm{B}$ (NF$\kappa \mathrm{B})$ activation (21). Seki et al. found that resolvin E1 protected mice from bacterial pneumonia and acute lung injury with pretreatment by decreased lung neutrophil accumulation, enhanced microbial clearance, decrease in lung pro-inflammatory mediators, and improved survival (20).

\section{VITAMIN D}

Recent evidence suggests an association between vitamin D levels and the risk of ARDS (199-201). Vitamin D deficiency is associated with impaired pulmonary function and increased incidence of viral and bacterial infections and inflammatory disease, including asthma and COPD (202-204). Mechanisms for these associations are unknown, but vitamin $\mathrm{D}$ plays a role in macrophage, lymphocyte, and epithelial cell function, critical to ARDS pathophysiology $(200,205)$.

\section{SUMMARY}

There are currently limited data to guide nutritional strategies in the critically ill pediatric patient and an absence of data targeted specifically at pARDS (Tables 2 and 3). Current strategies rely on the application of adult data, knowledge of the metabolic derangements caused by critical illness, and knowledge of the nutritional requirements of healthy children. The generally accepted strategy centers on the early identification of need for nutritional supplementation and early initiation of EN targeted toward fulfillment of nutritional goals and implemented by a collaborative, multidisciplinary treatment team. Indirect calorimetry is a recommended adjunct to ensure adequate, but not excessive, nutritional support is supplied. Early prescription of a bowel regimen to limit constipation while avoiding diarrhea is also recommended (50). PN is currently reserved for patients in whom EN is contraindicated or limited, though its routine use as a supplement to $\mathrm{EN}$ is an area ripe for research. Before we evaluate the role of immunonutrition to improve outcomes of pARDS, fundamental questions regarding protein and energy requirements during pARDS remain: if delivery should be based on premorbid nutritional risk and if under, normo, or even overfeeding might be beneficial at different stages of illness. Given the mortality benefit of nutritional adequacy on pARDS, it may prove challenging to identify benefits of adjuvant nutritional therapies, unless they are overlaid upon a foundation of adequate macronutrient delivery. Once fundamental questions regarding optimal timing, dose, and route of macronutrient delivery are answered for pARDS, investigations centered on immunonutrition to further improve patient outcomes are appropriate. Systematic investigations to determine the impact 
of each pharmaconutrient separately and in combination during pARDS are necessary.

In the future, intensivists will likely employ distinct and highly personalized nutritional therapies based on patient premorbid nutritional risk, admission diagnosis, severity of illness, measured energy expenditure, active monitoring of lean body mass, and the composition of patient intestinal microbiome. A select group of high-risk patients are likely to experience benefit from an intensive and personalized, titrated nutritional plan. Long-stay patients, patients with ARDS, sepsis, burns, or preexisting severe malnutrition are most likely to have improved outcomes if nutrition is closely monitored. Intensive nutritional therapies will likely be titrated daily to meet energy and protein needs. Nutritional therapies, monitoring, and impact on meaningful patient outcomes are likely to change dramatically in the next decade as we understand the role of the microbiome in regulating both intestinal health and also the inflammatory response to pARDS. We may require nutritional or "metabolic" teams to precisely tailor metabolic support to meet, but not exceed, energy, protein, and micronutrient needs, preserve lean

\section{REFERENCES}

1. American Academy of Pediatrics, Committee on Nutrition, Barness LA. Pediatric Nutrition Handbook. 6th ed. Elk Grove Village, IL: American Academy of Pediatrics (2009).

2. Mehta NM, Bechard LJ, Zurakowski D, Duggan CP, Heyland DK. Adequate enteral protein intake is inversely associated with 60 -d mortality in critically ill children: a multicenter, prospective, cohort study. Am J Clin Nutr (2015) 102:199-206. doi:10.3945/ajcn.114.104893

3. Mehta NM, Bechard LJ, Cahill N, Wang M, Day A, Duggan CP, et al. Nutritional practices and their relationship to clinical outcomes in critically ill children - an international multicenter cohort study*. Crit Care Med (2012) 40:2204-11. doi:10.1097/CCM.0b013e31824e18a8

4. Wong JJ, Han WM, Sultana R, Loh TF, Lee JH. Nutrition delivery affects outcomes in pediatric acute respiratory distress syndrome. JPEN J Parenter Enteral Nutr (2016). doi:10.1177/0148607116637937

5. de Neef M, Geukers VG, Dral A, Lindeboom R, Sauerwein HP, Bos AP. Nutritional goals, prescription and delivery in a pediatric intensive care unit. Clin Nutr (2008) 27:65-71. doi:10.1016/j.clnu.2007.10.013

6. Hulst J, Joosten K, Zimmermann L, Hop W, van Buuren S, Büller H, et al. Malnutrition in critically ill children: from admission to 6 months after discharge. Clin Nutr (2004) 23:223-32. doi:10.1016/S0261-5614(03)00130-4

7. Hulst JM, Joosten KF, Tibboel D, van Goudoever JB. Causes and consequences of inadequate substrate supply to pediatric ICU patients. Curr Opin Clin Nutr Metab Care (2006) 9:297-303. doi:10.1097/01.mco.0000222115.91783.71

8. Malakouti A, Sookplung P, Siriussawakul A, Philip S, Bailey N, Brown M, et al. Nutrition support and deficiencies in children with severe traumatic brain injury. Pediatr Crit Care Med (2012) 13:e18-24. doi:10.1097/ PCC.0b013e31820aba1f

9. Mehta NM, McAleer D, Hamilton S, Naples E, Leavitt K, Mitchell P, et al. Challenges to optimal enteral nutrition in a multidisciplinary pediatric intensive care unit. JPEN JParenter Enteral Nutr (2010) 34:38-45. doi:10.1177/0148607109348065

10. Pollack MM, Ruttimann UE, Wiley JS. Nutritional depletions in critically ill children: associations with physiologic instability and increased quantity of care. JPEN J Parenter Enteral Nutr (1985) 9:309-13. doi:10.1177/014860718 5009003309

11. Rendon JL, Choudhry MA. Th17 cells: critical mediators of host responses to burn injury and sepsis. JLeukoc Biol (2012) 92:529-38. doi:10.1189/ jlb.0212083

12. Ichinohe T, Pang IK, Kumamoto Y, Peaper DR, Ho JH, Murray TS, et al. Microbiota regulates immune defense against respiratory tract influenza body mass, the microbiome, the virome, and intestinal barrier functions. Nutrition is fundamental to provision of critical care services, and, with an understanding of the complex role it plays in illness and health, we will be able to design effective clinical trials of nutritional interventions as primary therapies for pARDS.

\section{AUTHOR CONTRIBUTIONS}

Dr. BW and Dr. KT contributed equally to the conception, review of literature, writing, and editing of this manuscript. Both authors approve of the final submitted version of this manuscript.

\section{FUNDING}

Dr. KT is supported by the National Institute of Diabetes and Digestive and Kidney Diseases (NIDDK) of the National Institutes of Health, under the award number K23DK106462. Dr. KT is supported by the Arizona Health Sciences Career Development Award.

A virus infection. Proc Natl Acad Sci U S A (2011) 108:5354-9. doi:10.1073/ pnas. 1019378108

13. Sodhi CP, Jia H, Yamaguchi Y, Lu P, Good M, Egan C, et al. Intestinal epithelial TLR-4 activation is required for the development of acute lung injury after trauma/hemorrhagic shock via the release of HMGB1 from the gut. J Immunol (2015) 194:4931-9. doi:10.4049/jimmunol.1402490

14. Galperin C, Gershwin ME. Immunopathogenesis of gastrointestinal and hepatobiliary diseases. JAMA (1997) 278:1946-55. doi:10.1001/ jama.278.22.1946

15. Kudsk KA. Effect of route and type of nutrition on intestine-derived inflammatory responses. Am JSurg (2003) 185:16-21. doi:10.1016/ S0002-9610(02)01146-7

16. Janu P, Li J, Renegar KB, Kudsk KA. Recovery of gut-associated lymphoid tissue and upper respiratory tract immunity after parenteral nutrition. Ann Surg (1997)225:707-15; discussion 15-7.doi:10.1097/00000658-199706000-00008

17. Turner JR. Intestinal mucosal barrier function in health and disease. Nat Rev Immunol (2009) 9:799-809. doi:10.1038/nri2653

18. Pathan N, Burmester M, Adamovic T, Berk M, Ng KW, Betts H, et al. Intestinal injury and endotoxemia in children undergoing surgery for congenital heart disease. Am J Respir Crit Care Med (2011) 184:1261-9. doi:10.1164/ rccm.201104-0715OC

19. Fukatsu K, Zarzaur BL, Johnson CD, Lundberg AH, Wilcox HG, Kudsk KA. Enteral nutrition prevents remote organ injury and death after a gut ischemic insult. Ann Surg (2001) 233:660-8. doi:10.1097/00000658-200105000-00010

20. Seki H, Fukunaga K, Arita M, Arai H, Nakanishi H, Taguchi R, et al. The anti-inflammatory and proresolving mediator resolvin $\mathrm{E} 1$ protects mice from bacterial pneumonia and acute lung injury. J Immunol (2010) 184:836-43. doi:10.4049/jimmunol.0901809

21. Eickmeier O, Seki H, Haworth O, Hilberath JN, Gao F, Uddin M, et al. Aspirin-triggered resolvin D1 reduces mucosal inflammation and promotes resolution in a murine model of acute lung injury. Mucosal Immunol (2013) 6:256-66. doi:10.1038/mi.2012.66

22. Jacobs BR, Nadkarni V, Goldstein B, Checchia P, Ayad O, Bean J, et al Nutritional immunomodulation in critically ill children with acute lung injury: feasibility and impact on circulating biomarkers. Pediatr Crit Care Med (2013) 14:e45-56. doi:10.1097/PCC.0b013e31827124f3

23. Duggan C, Watkins J, Walker WA. Nutrition in Pediatrics: Basic Science, Clinical Application. 4th ed. Hamilton: BC Decker (2008).

24. Mehta NM, Duggan CP. Nutritional deficiencies during critical illness. Pediatr Clin North Am (2009) 56:1143-60. doi:10.1016/j.pcl.2009.06.007

25. Graciano AL, Turner DA, editors. Current Concepts in Pediatric Critical Care. Mount Prospect, IL: Society of Critical Care Medicine (2015). 
26. Bechard LJ, Duggan C, Touger-Decker R, Parrott JS, Rothpletz-Puglia P, Byham-Gray L, et al. Nutritional status based on body mass index is associated with morbidity and mortality in mechanically ventilated critically ill children in the PICU. Crit Care Med (2016) 44:1530-7. doi:10.1097/ CCM.0000000000001713

27. de Souza Menezes F, Leite HP, Koch Nogueira PC. Malnutrition as an independent predictor of clinical outcome in critically ill children. Nutrition (2012) 28:267-70. doi:10.1016/j.nut.2011.05.015

28. Delgado AF, Okay TS, Leone C, Nichols B, Del Negro GM, Vaz FA. Hospital malnutrition and inflammatory response in critically ill children and adolescents admitted to a tertiary intensive care unit. Clinics (Sao Paulo) (2008) 63:357-62. doi:10.1590/S1807-59322008000300012

29. Dobbing J, Sands J. Vulnerability of developing brain. IX. The effect of nutritional growth retardation on the timing of the brain growth-spurt. Biol Neonate (1971) 19:363-78. doi:10.1159/000240430

30. Ehrenkranz RA, Das A, Wrage LA, Poindexter BB, Higgins RD, Stoll BJ, et al. Early nutrition mediates the influence of severity of illness on extremely LBW infants. Pediatr Res (2011) 69:522-9. doi:10.1203/PDR.0b013e318217f4f1

31. Radman M, Mack R, Barnoya J, Castañeda A, Rosales M, Azakie A, et al. The effect of preoperative nutritional status on postoperative outcomes in children undergoing surgery for congenital heart defects in San Francisco (UCSF) and Guatemala City (UNICAR). J Thorac Cardiovasc Surg (2014) 147:442-50. doi:10.1016/j.jtcvs.2013.03.023

32. Briassoulis G, Zavras N, Hatzis T. Malnutrition, nutritional indices, and early enteral feeding in critically ill children. Nutrition (2001) 17:548-57. doi:10.1016/S0899-9007(01)00578-0

33. Pollack MM, Wiley JS, Holbrook PR. Early nutritional depletion in critically ill children. Crit Care Med (1981) 9:580-3. doi:10.1097/00003246198108000-00005

34. Pollack MM, Wiley JS, Kanter R, Holbrook PR. Malnutrition in critically ill infants and children. JPEN J Parenter Enteral Nutr (1982) 6:20-4. doi:10.1177/014860718200600120

35. Prieto MB, Cid JL. Malnutrition in the critically ill child: the importance of enteral nutrition. Int J Environ Res Public Health (2011) 8:4353-66. doi:10.3390/ijerph8114353

36. Mikhailov TA, Kuhn EM, Manzi J, Christensen M, Collins M, Brown AM, et al. Early enteral nutrition is associated with lower mortality in critically ill children. JPEN J Parenter Enteral Nutr (2014) 38(4):459-66. doi:10.1177/ 0148607113517903

37. Lopez-Herce J, Santiago MJ, Sanchez C, Mencia S, Carrillo A, Vigil D. Risk factors for gastrointestinal complications in critically ill children with transpyloric enteral nutrition. Eur J Clin Nutr (2008) 62:395-400. doi:10.1038/ sj.ejcn. 1602710

38. Panchal AK, Manzi J, Connolly S, Christensen M, Wakeham M, Goday PS, et al. Safety of enteral feedings in critically ill children receiving vasoactive agents. JPEN J Parenter Enteral Nutr (2016) 40(2):236-41. doi:10.1177/0148607114546533

39. Ogden CL, Carroll MD, Curtin LR, McDowell MA, Tabak CJ, Flegal KM. Prevalence of overweight and obesity in the United States, 1999-2004. JAMA (2006) 295:1549-55. doi:10.1001/jama.295.13.1549

40. Robinson MK, Mogensen KM, Casey JD, McKane CK, Moromizato T, Rawn JD, et al. The relationship among obesity, nutritional status, and mortality in the critically ill. Crit Care Med (2015) 43:87-100. doi:10.1097/ CCM.0000000000000602

41. Stapleton RD, Suratt BT. Obesity and nutrition in acute respiratory distress syndrome. Clin Chest Med (2014) 35:655-71. doi:10.1016/j.ccm.2014.08.005

42. Mehta NM, Corkins MR, Lyman B, Malone A, Goday PS, Carney LN, et al. Defining pediatric malnutrition: a paradigm shift toward etiology-related definitions. JPEN J Parenter Enteral Nutr (2013) 37:460-81. doi:10.1177/0148607113479972

43. Keshen TH, Miller RG, Jahoor F, Jaksic T. Stable isotopic quantitation of protein metabolism and energy expenditure in neonates on- and postextracorporeal life support. J Pediatr Surg (1997) 32:958-62; discussion 62-3. doi:10.1016/S0022-3468(97)90377-8

44. Agus MS, Javid PJ, Piper HG, Wypij D, Duggan CP, Ryan DP, et al. The effect of insulin infusion upon protein metabolism in neonates on extracorporeal life support. Ann Surg (2006) 244:536-44. doi:10.1097/01.sla.0000237758. 93186.c8
45. Botran M, Lopez-Herce J, Mencia S, Urbano J, Solana MJ, Garcia A. Enteral nutrition in the critically ill child: comparison of standard and protein-enriched diets. J Pediatr (2011) 159:27-32. doi:10.1016/j.jpeds.2011. 02.001

46. Liebau F, Wernerman J, van Loon LJ, Rooyackers O. Effect of initiating enteral protein feeding on whole-body protein turnover in critically ill patients. Am J Clin Nutr (2015) 101:549-57. doi:10.3945/ajcn.114.091934

47. Bechard LJ, Parrott JS, Mehta NM. Systematic review of the influence of energy and protein intake on protein balance in critically ill children. J Pediatr (2012) 161(333-9):e1. doi:10.1016/j.jpeds.2012.01.046

48. Goldman HI, Freudenthal R, Holland B, Karelitz S. Clinical effects of two different levels of protein intake on low-birth-weight infants. J Pediatr (1969) 74:881-9. doi:10.1016/S0022-3476(69)80222-2

49. Goldman HI, Liebman OB, Freudenthal R, Reuben R. Effects of early dietary protein intake on low-birth-weight infants: evaluation at 3 years of age. J Pediatr (1971) 78:126-9. doi:10.1016/S0022-3476(71)80277-9

50. Mehta NM, Compher C, A.S.P.E.N. Board of Directors. A.S.P.E.N. Clinical Guidelines: nutrition support of the critically ill child. JPEN J Parenter Enteral Nutr (2009) 33:260-76. doi:10.1177/0148607109333114

51. Coss-Bu JA, Jefferson LS, Walding D, David Y, Smith EO, Klish WJ. Resting energy expenditure in children in a pediatric intensive care unit: comparison of Harris-Benedict and Talbot predictions with indirect calorimetry values. Am J Clin Nutr (1998) 67:74-80.

52. Leong AY, Field CJ, Larsen BM. Nutrition support of the postoperative cardiac surgery child. Nutr Clin Pract (2013) 28:572-9. doi:10.1177/0884533613 497515

53. Mehta NM, Bechard LJ, Dolan M, Ariagno K, Jiang H, Duggan C. Energy imbalance and the risk of overfeeding in critically ill children. Pediatr Crit Care Med (2011) 12:398-405. doi:10.1097/PCC.0b013e3181fe279c

54. Briassoulis G, Venkataraman S, Thompson A. Cytokines and metabolic patterns in pediatric patients with critical illness. Clin Dev Immunol (2010) 2010:354047. doi:10.1155/2010/354047

55. De Wit B, Meyer R, Desai A, Macrae D, Pathan N. Challenge of predicting resting energy expenditure in children undergoing surgery for congenital heart disease. Pediatr Crit Care Med (2010) 11:496-501. doi:10.1097/ PCC.0b013e3181ce7465

56. Framson CM, LeLeiko NS, Dallal GE, Roubenoff R, Snelling LK, Dwyer JT. Energy expenditure in critically ill children. Pediatr Crit Care Med (2007) 8:264-7. doi:10.1097/01.PCC.0000262802.81164.03

57. Mehta NM, Bechard LJ, Leavitt K, Duggan C. Cumulative energy imbalance in the pediatric intensive care unit: role of targeted indirect calorimetry. JPEN J Parenter Enteral Nutr (2009) 33:336-44. doi:10.1177/0148607108325249

58. Franz AR, Pohlandt F, Bode H, Mihatsch WA, Sander S, Kron M, et al. Intrauterine, early neonatal, and postdischarge growth and neurodevelopmental outcome at 5.4 years in extremely preterm infants after intensive neonatal nutritional support. Pediatrics (2009) 123:e101-9. doi:10.1542/ peds.2008-1352

59. Lucas A, Morley R, Cole TJ. Randomised trial of early diet in preterm babies and later intelligence quotient. BMJ (1998) 317:1481-7. doi:10.1136/ bmj.317.7171.1481

60. Letton RW, Chwals WJ, Jamie A, Charles B. Early postoperative alterations in infant energy use increase the risk of overfeeding. J Pediatr Surg (1995) 30:988-92; discussion 92-3. doi:10.1016/0022-3468(95)90327-5

61. Pons Leite H, Gilberto Henriques Vieira J, Burnow De Carvalho W, Chwals WJ. The role of insulin-like growht factor I, growth hormone, and plasma proteins in surgical outcome of children with congenital heart disease. Pediatr Crit Care Med (2001) 2:29-35. doi:10.1097/00130478-20010 1000-00007

62. Alaedeen DI, Walsh MC, Chwals WJ. Total parenteral nutrition-associated hyperglycemia correlates with prolonged mechanical ventilation and hospital stay in septic infants. J Pediatr Surg (2006) 41:239-44; discussion 239-44. doi:10.1016/j.jpedsurg.2005.10.045

63. Long CL, Kinney JM, Geiger JW. Nonsuppressability of gluconeogenesis by glucose in septic patients. Metabolism (1976) 25:193-201. doi:10.1016/0026-0495(76)90049-4

64. Powis MR, Smith K, Rennie M, Halliday D, Pierro A. Effect of major abdominal operations on energy and protein metabolism in infants and children. J Pediatr Surg (1998) 33:49-53. doi:10.1016/S0022-3468(98)90360-8 
65. Srinivasan V. Stress hyperglycemia in pediatric critical illness: the intensive care unit adds to the stress! J Diabetes Sci Technol (2012) 6:37-47. doi:10.1177/193229681200600106

66. Van Herpe T, Vanhonsebrouck K, Mesotten D, De Moor B, Van den Berghe G. Glycemic control in the pediatric intensive care unit of Leuven: two years of experience. JDiabetes Sci Technol (2012) 6:15-21. doi:10.1177/193229681200600103

67. Feng Y, Ralls MW, Xiao W, Miyasaka E, Herman RS, Teitelbaum DH. Loss of enteral nutrition in a mouse model results in intestinal epithelial barrier dysfunction. Ann N Y Acad Sci (2012) 1258:71-7. doi:10.1111/ j.1749-6632.2012.06572.x

68. Johnson CD, Kudsk KA, Fukatsu K, Renegar KB, Zarzaur BL. Route of nutrition influences generation of antibody-forming cells and initial defense to an active viral infection in the upper respiratory tract. Ann Surg (2003) 237:565-73. doi:10.1097/00000658-200304000-00019

69. Ohta K, Omura K, Hirano K, Kanehira E, Ishikawa N, Kato Y, et al. The effects of an additive small amount of a low residual diet against total parenteral nutrition-induced gut mucosal barrier. Am J Surg (2003) 185:79-85. doi:10.1016/S0002-9610(02)01108-X

70. Sacks GS, Kudsk KA. Maintaining mucosal immunity during parenteral feeding with surrogates to enteral nutrition. Nutr Clin Pract (2003) 18:483-8. doi: $10.1177 / 0115426503018006483$

71. Shankar B, Daphnee DK, Ramakrishnan N, Venkataraman R. Feasibility, safety, and outcome of very early enteral nutrition in critically ill patients: results of an observational study. J Crit Care (2015) 30:473-5. doi:10.1016/j. jcrc.2015.02.009

72. Valentine SL, Nadkarni VM, Curley MA, Pediatric Acute Lung Injury Consensus Conference Group. Nonpulmonary treatments for pediatric acute respiratory distress syndrome: proceedings from the Pediatric Acute Lung Injury Consensus Conference. Pediatr Crit Care Med (2015) 16:S73-85. doi:10.1097/PCC.0000000000000435

73. Harvey SE, Parrott F, Harrison DA, Bear DE, Segaran E, Beale R, et al. Trial of the route of early nutritional support in critically ill adults. $N$ Engl J Med (2014) 371(18):1673-84. doi:10.1056/NEJMoa1409860

74. Charles EJ, Petroze RT, Metzger R, Hranjec T, Rosenberger LH, Riccio LM, et al. Hypocaloric compared with eucaloric nutritional support and its effect on infection rates in a surgical intensive care unit: a randomized controlled trial. Am J Clin Nutr (2014) 100:1337-43. doi:10.3945/ajcn.114.088609

75. Choi EY, Park DA, Park J. Calorie intake of enteral nutrition and clinical outcomes in acutely critically ill patients: a meta-analysis of randomized controlled trials. JPEN J Parenter Enteral Nutr (2015) 39:291-300. doi:10.1177/ 0148607114544322

76. Dickerson RN, Boschert KJ, Kudsk KA, Brown RO. Hypocaloric enteral tube feeding in critically ill obese patients. Nutrition (2002) 18:241-6. doi:10.1016/ S0899-9007(01)00793-6

77. Hart DW, Wolf SE, Herndon DN, Chinkes DL, Lal SO, Obeng MK, et al. Energy expenditure and caloric balance after burn: increased feeding leads to fat rather than lean mass accretion. Ann Surg (2002) 235:152-61. doi:10.1097/00000658-200201000-00020

78. Krishnan JA, Parce PB, Martinez A, Diette GB, Brower RG. Caloric intake in medical ICU patients: consistency of care with guidelines and relationship to clinical outcomes. Chest (2003) 124:297-305. doi:10.1378/chest. 124.1.297

79. Tian F, Wang X, Gao X, Wan X, Wu C, Zhang L, et al. Effect of initial calorie intake via enteral nutrition in critical illness: a meta-analysis of randomised controlled trials. Crit Care (2015) 19:180. doi:10.1186/s13054-015-0902-0

80. Dokken M, Rustoen T, Stubhaug A. Indirect calorimetry reveals that better monitoring of nutrition therapy in pediatric intensive care is needed. JPEN J Parenter Enteral Nutr (2015) 39:344-52. doi:10.1177/0148607113511990

81. Preiser JC, van Zanten AR, Berger MM, Biolo G, Casaer MP, Doig GS, et al. Metabolic and nutritional support of critically ill patients: consensus and controversies. Crit Care (2015) 19:35. doi:10.1186/s13054-015-0737-8

82. Berger MM, Chiolero RL. Hypocaloric feeding: pros and cons. Curr Opin Crit Care (2007) 13:180-6. doi:10.1097/MCC.0b013e3280895d47

83. Derde S, Vanhorebeek I, Güiza F, Derese I, Gunst J, Fahrenkrog B, et al. Early parenteral nutrition evokes a phenotype of autophagy deficiency in liver and skeletal muscle of critically ill rabbits. Endocrinology (2012) 153:2267-76. doi:10.1210/en.2011-2068
84. Fivez T, Kerklaan D, Mesotten D, Verbruggen S, Wouters PJ, Vanhorebeek I, et al. Early versus late parenteral nutrition in critically ill children. $N$ Engl J Med (2016) 374:1111-22. doi:10.1056/NEJMoa1514762

85. Harvey SE, Parrott F, Harrison DA, Bear DE, Segaran E, Beale R, et al. Trial of the route of early nutritional support in critically ill adults. N Engl J Med (2014) 371:1673-84. doi:10.1056/NEJMoa1409860

86. Doig GS, Simpson F, Sweetman EA, Finfer SR, Cooper DJ, Heighes PT, et al. Early parenteral nutrition in critically ill patients with short-term relative contraindications to early enteral nutrition: a randomized controlled trial. JAMA (2013) 309:2130-8. doi:10.1001/jama.2013.5124

87. Heidegger CP, Berger MM, Graf S, Zingg W, Darmon P, Costanza MC, et al. Optimisation of energy provision with supplemental parenteral nutrition in critically ill patients: a randomised controlled clinical trial. Lancet (2013) 381:385-93. doi:10.1016/S0140-6736(12)61351-8

88. Casaer MP, Mesotten D, Hermans G, Wouters PJ, Schetz M, Meyfroidt G, et al. Early versus late parenteral nutrition in critically ill adults. $N$ Engl J Med (2011) 365:506-17. doi:10.1056/NEJMoa1102662

89. Arabi YM, Aldawood AS, Haddad SH, Al-Dorzi HM, Tamim HM, Jones G, et al. Permissive underfeeding or standard enteral feeding in critically ill adults. N Engl J Med (2015) 372:2398-408. doi:10.1056/NEJMoa1502826

90. Braunschweig CA, Sheean PM, Peterson SJ, Gomez Perez S, Freels S, Lateef O, et al. Intensive nutrition in acute lung injury: a clinical trial (INTACT). JPEN J Parenter Enteral Nutr (2015) 39:13-20. doi:10.1177/0148607114528541

91. National Heart, Lung, and Blood Institute Acute Respiratory Distress Syndrome Clinical Trials Network, Rice TW, Wheeler AP, Thompson BT, Steingrub J, Hite RD, et al. Initial trophic vs full enteral feeding in patients with acute lung injury: the EDEN randomized trial. JAMA (2012) 307:795-803. doi:10.1001/jama.2012.137

92. Davies AR, Morrison SS, Bailey MJ, Bellomo R, Cooper DJ, Doig GS, et al. A multicenter, randomized controlled trial comparing early nasojejunal with nasogastric nutrition in critical illness. Crit Care Med (2012) 40:2342-8. doi:10.1097/CCM.0b013e318255d87e

93. Acosta-Escribano J, Fernández-Vivas M, Grau Carmona T, Caturla-Such J, Garcia-Martinez M, Menendez-Mainer A, et al. Gastric versus transpyloric feeding in severe traumatic brain injury: a prospective, randomized trial. Intensive Care Med (2010) 36:1532-9. doi:10.1007/s00134-010-1908-3

94. Hsu CW, Sun SF, Lin SL, Kang SP, Chu KA, Lin CH, et al. Duodenal versus gastric feeding in medical intensive care unit patients: a prospective, randomized, clinical study. Crit Care Med (2009) 37:1866-72. doi:10.1097/ CCM.0b013e31819ffcda

95. Khorasani EN, Mansouri F. Effect of early enteral nutrition on morbidity and mortality in children with burns. Burns (2010) 36:1067-71. doi:10.1016/j. burns.2009.12.005

96. MacLeod JB, Lefton J, Houghton D, Roland C, Doherty J, Cohn SM, et al. Prospective randomized control trial of intermittent versus continuous gastric feeds for critically ill trauma patients. J Trauma (2007) 63:57-61. doi:10.1097/01.ta.0000249294.58703.11

97. NICE-SUGAR Study Investigators, Finfer S, Chittock DR, Su SY, Blair D, Foster D, et al. Intensive versus conventional glucose control in critically ill patients. N Engl J Med (2009) 360:1283-97. doi:10.1056/NEJMoa0810625

98. Vlasselaers D, Milants I, Desmet L, Wouters PJ, Vanhorebeek I, van den Heuvel I, et al. Intensive insulin therapy for patients in paediatric intensive care: a prospective, randomised controlled study. Lancet (2009) 373:547-56. doi:10.1016/S0140-6736(09)60044-1

99. Van den Berghe G, Wilmer A, Hermans G, Meersseman W, Wouters PJ, Milants I, et al. Intensive insulin therapy in the medical ICU. N Engl J Med (2006) 354:449-61. doi:10.1056/NEJMoa052521

100. Ziegler TR, May AK, Hebbar G, Easley KA, Griffith DP, Dave N, et al. Efficacy and safety of glutamine-supplemented parenteral nutrition in surgical ICU patients: an American Multicenter Randomized Controlled Trial. Ann Surg (2016) 263:646-55. doi:10.1097/SLA.0000000000001487

101. Pérez-Bárcena J, Marsé P, Zabalegui-Pérez A, Corral E, Herrán-Monge R, Gero-Escapa M, et al. A randomized trial of intravenous glutamine supplementation in trauma ICU patients. Intensive Care Med (2014) 40:539-47. doi:10.1007/s00134-014-3230-y

102. Heyland D, Muscedere J, Wischmeyer PE, Cook D, Jones G, Albert M, et al. A randomized trial of glutamine and antioxidants in critically ill patients. N Engl J Med (2013) 368:1489-97. doi:10.1056/NEJMoa1212722 
103. Carcillo JA, Dean JM, Holubkov R, Berger J, Meert KL, Anand KJ, et al. The randomized comparative pediatric critical illness stress-induced immune suppression (CRISIS) prevention trial. Pediatr Crit Care Med (2012) 13:165-73. doi:10.1097/PCC.0b013e31823896ae

104. Andrews PJ, Avenell A, Noble DW, Campbell MK, Croal BL, Simpson WG, et al. Randomised trial of glutamine, selenium, or both, to supplement parenteral nutrition for critically ill patients. BMJ (2011) 342:d1542. doi:10.1136/ bmj.d1542

105. Angstwurm MW, Engelmann L, Zimmermann T, Lehmann C, Spes CH, Abel $\mathrm{P}$, et al. Selenium in intensive care (SIC): results of a prospective randomized, placebo-controlled, multiple-center study in patients with severe systemic inflammatory response syndrome, sepsis, and septic shock. Crit Care Med (2007) 35:118-26. doi:10.1097/01.CCM.0000251124.83436.0E

106. Grau-Carmona T, Bonet-Saris A, Garcia-de-Lorenzo A, Sánchez-Alvarez C, Rodríguez-Pozo A, Acosta-Escribano J, et al. Influence of n-3 polyunsaturated fatty acids enriched lipid emulsions on nosocomial infections and clinical outcomes in critically ill patients: ICU lipids study. Crit Care $\operatorname{Med}(2015)$ 43:31-9.

107. Kagan I, Cohen J, Stein M, Bendavid I, Pinsker D, Silva V, et al. Preemptive enteral nutrition enriched with eicosapentaenoic acid, gamma-linolenic acid and antioxidants in severe multiple trauma: a prospective, randomized, double-blind study. Intensive Care Med (2015) 41:460-9. doi:10.1007/ s00134-015-3646-z

108. van Zanten AR, Sztark F, Kaisers UX, Zielmann S, Felbinger TW, Sablotzki AR, et al. High-protein enteral nutrition enriched with immune-modulating nutrients vs standard high-protein enteral nutrition and nosocomial infections in the ICU: a randomized clinical trial. JAMA (2014) 312:514-24. doi:10.1001/jama.2014.7698

109. Pontes-Arruda A, Martins LF, de Lima SM, Isola AM, Toledo D, Rezende E, et al. Enteral nutrition with eicosapentaenoic acid, gamma-linolenic acid and antioxidants in the early treatment of sepsis: results from a multicenter, prospective, randomized, double-blinded, controlled study: the INTERSEPT study. Crit Care (2011) 15:R144. doi:10.1186/cc10267

110. Radrizzani D, Bertolini G, Facchini R, Simini B, Bruzzone P, Zanforlin G, et al. Early enteral immunonutrition vs. parenteral nutrition in critically ill patients without severe sepsis: a randomized clinical trial. Intensive Care Med (2006) 32:1191-8. doi:10.1007/s00134-006-0238-y

111. Czapran A, Headdon W, Deane AM, Lange K, Chapman MJ, Heyland DK. International observational study of nutritional support in mechanically ventilated patients following burn injury. Burns (2015) 41:510-8. doi:10.1016/j. burns.2014.09.013

112. Peev MP, Yeh DD, Quraishi SA, Osler P, Chang Y, Gillis E, et al. Causes and consequences of interrupted enteral nutrition: a prospective observational study in critically ill surgical patients. JPEN J Parenter Enteral Nutr (2015) 39:21-7. doi:10.1177/0148607114526887

113. Weijs PJ, Looijaard WG, Beishuizen A, Girbes AR, Oudemans-van Straaten HM. Early high protein intake is associated with low mortality and energy overfeeding with high mortality in non-septic mechanically ventilated critically ill patients. Crit Care (2014) 18:701. doi:10.1186/s13054-014-0701-z

114. Alberda C, Gramlich L, Jones N, Jeejeebhoy K, Day AG, Dhaliwal R, et al. The relationship between nutritional intake and clinical outcomes in critically ill patients: results of an international multicenter observational study. Intensive Care Med (2009) 35:1728-37. doi:10.1007/s00134-009-1567-4

115. Canarie MF, Barry S, Carroll CL, Hassinger A, Kandil S, Li S, et al. Risk factors for delayed enteral nutrition in critically Ill children. Pediatr Crit Care Med (2015) 16:e283-9. doi:10.1097/PCC.0000000000000527

116. Martinez EE, Smallwood CD, Bechard LJ, Graham RJ, Mehta NM. Metabolic assessment and individualized nutrition in children dependent on mechanical ventilation at home. J Pediatr (2015) 166:350-7. doi:10.1016/j. jpeds.2014.09.036

117. Tillquist M, Kutsogiannis DJ, Wischmeyer PE, Kummerlen C, Leung R, Stollery D, et al. Bedside ultrasound is a practical and reliable measurement tool for assessing quadriceps muscle layer thickness. JPEN J Parenter Enteral Nutr (2014) 38:886-90. doi:10.1177/0148607113501327

118. Savalle M, Gillaizeau F, Maruani G, Puymirat E, Bellenfant F, Houillier P, et al. Assessment of body cell mass at bedside in critically ill patients. Am J Physiol Endocrinol Metab (2012) 303:E389-96. doi:10.1152/ajpendo.00502.2011

119. Sheean PM, Peterson SJ, Gomez Perez S, Troy KL, Patel A, Sclamberg JS, et al. The prevalence of sarcopenia in patients with respiratory failure classified as normally nourished using computed tomography and subjective global assessment. JPEN J Parenter Enteral Nutr (2014) 38:873-9. doi: $10.1177 / 0148607113500308$

120. Meert KL, Daphtary KM, Metheny NA. Gastric vs small-bowel feeding in critically ill children receiving mechanical ventilation: a randomized controlled trial. Chest (2004) 126:872-8. doi:10.1378/chest.126.3.872

121. Wang D, Zheng SQ, Chen XC, Jiang SW, Chen HB. Comparisons between small intestinal and gastric feeding in severe traumatic brain injury: a systematic review and meta-analysis of randomized controlled trials. J Neurosurg (2015) 123:1194-201. doi:10.3171/2014.11.JNS141109

122. Lopez-Herce J, Mencia S, Sanchez C, Santiago MJ, Bustinza A, Vigil D. Postpyloric enteral nutrition in the critically ill child with shock: a prospective observational study. Nutr J (2008) 7:6. doi:10.1186/1475-2891-7-6

123. Fivez T, Kerklaan D, Verbruggen S, Vanhorebeek I, Verstraete S, Tibboel D, et al. Impact of withholding early parenteral nutrition completing enteral nutrition in pediatric critically ill patients (PEPaNIC trial): study protocol for a randomized controlled trial. Trials (2015) 16:202. doi:10.1186/ s13063-015-0728-8

124. Denne SC, Poindexter BB. Evidence supporting early nutritional support with parenteral amino acid infusion. Semin Perinatol (2007) 31:56-60. doi:10.1053/j.semperi.2007.02.005

125. Evans RA, Thureen P. Early feeding strategies in preterm and critically ill neonates. Neonatal Netw (2001) 20:7-18. doi:10.1891/0730-0832.20.7.7

126. Grau-Carmona T, Bonet-Saris A, García-de-Lorenzo A, Sánchez-Alvarez C, Rodríguez-Pozo A, Acosta-Escribano J, et al. Influence of n-3 polyunsaturated fatty acids enriched lipid emulsions on nosocomial infections and clinical outcomes in critically ill patients: ICU lipids study. Crit Care Med (2015) 43:31-9. doi:10.1097/CCM.0000000000000612

127. Grintescu IM, Luca Vasiliu I, Cucereanu Badica I, Mirea L, Pavelescu D, Balanescu A, et al. The influence of parenteral glutamine supplementation on glucose homeostasis in critically ill polytrauma patients - a randomized-controlled clinical study. Clin Nutr (2015) 34:377-82. doi:10.1016/j. clnu.2014.05.006

128. Najmi M, Vahdat Shariatpanahi Z, Tolouei M, Amiri Z. Effect of oral olive oil on healing of $10-20 \%$ total body surface area burn wounds in hospitalized patients. Burns (2015) 41:493-6. doi:10.1016/j.burns.2014.08.010

129. Zhang WC, Zheng XJ, Du LJ, Sun JY, Shen ZX, Shi C, et al. High salt primes a specific activation state of macrophages, M(Na). Cell Res (2015) 25:893-910. doi:10.1038/cr.2015.87

130. King W, Petrillo T, Pettignano R. Enteral nutrition and cardiovascular medications in the pediatric intensive care unit. JPEN J Parenter Enteral Nutr (2004) 28:334-8. doi:10.1177/0148607104028005334

131. Rogers EJ, Gilbertson HR, Heine RG, Henning R. Barriers to adequate nutrition in critically ill children. Nutrition (2003) 19:865-8. doi:10.1016/ S0899-9007(03)00170-9

132. Khalid I, Doshi P, DiGiovine B. Early enteral nutrition and outcomes of critically ill patients treated with vasopressors and mechanical ventilation. Am J Crit Care (2010) 19:261-8. doi:10.4037/ajcc2010197

133. McClave SA, Lukan JK, Stefater JA, Lowen CC, Looney SW, Matheson PJ, et al. Poor validity of residual volumes as a marker for risk of aspiration in critically ill patients. Crit Care Med (2005) 33:324-30. doi:10.1097/01. CCM.0000153413.46627.3A

134. Metheny NA, Mills AC, Stewart BJ. Monitoring for intolerance to gastric tube feedings: a national survey. Am J Crit Care (2012) 21:e33-40. doi:10.4037/ ajcc 2012647

135. Meyer R, Harrison S, Sargent S, Ramnarayan P, Habibi P, Labadarios D. The impactofenteralfeedingprotocolsonnutritionalsupportincriticallyillchildren. J Hum Nutr Diet (2009) 22:428-36. doi:10.1111/j.1365-277X.2009.00994.x

136. Blaser AR, Starkopf J, Kirsimagi U, Deane AM. Definition, prevalence, and outcome of feeding intolerance in intensive care: a systematic review and meta-analysis. Acta Anaesthesiol Scand (2014) 58:914-22. doi:10.1111/ aas. 12302

137. Smalley N, Vangaveti V. Assessing the bowel function of critically ill children: a pilot study. Crit Care Resusc (2014) 16(3):202-5.

138. Martinez EE, Douglas K, Nurko S, Mehta NM. Gastric dysmotility in critically ill children: pathophysiology, diagnosis, and management. Pediatr Crit Care Med (2015) 16:828-36. doi:10.1097/PCC.0000000000000493

139. Deane A, Chapman MJ, Fraser RJ, Bryant LK, Burgstad C, Nguyen NQ. Mechanisms underlying feed intolerance in the critically ill: implications for 
treatment. World J Gastroenterol (2007) 13:3909-17. doi:10.3748/wjg.v13. i29.3909

140. Typpo KV, Larmonier CB, Deschenes J, Redford D, Kiela PR, Ghishan FK. Clinical characteristics associated with postoperative intestinal epithelial barrier dysfunction in children with congenital heart disease. Pediatr Crit Care Med (2015) 16:37-44. doi:10.1097/PCC.0000000000000256

141. Reeves A, White H, Sosnowski K, Tran K, Jones M, Palmer M. Energy and protein intakes of hospitalised patients with acute respiratory failure receiving non-invasive ventilation. Clin Nutr (2014) 33:1068-73. doi:10.1016/j. clnu.2013.11.012

142. Ridley EJ, Davies AR, Robins EJ, Lukas G, Bailey MJ, Fraser JF, et al. Nutrition therapy in adult patients receiving extracorporeal membrane oxygenation: a prospective, multicentre, observational study. Crit Care Resusc (2015) 17:183-9.

143. Haskins IN, Baginsky M, Gamsky N, Sedghi K, Yi S, Amdur RL, et al. A volume-based enteral nutrition support regimen improves caloric delivery but may not affect clinical outcomes in critically ill patients. JPEN J Parenter Enteral Nutr (2015). doi:10.1177/0148607115617441

144. Hamilton S, McAleer DM, Ariagno K, Barrett M, Stenquist N, Duggan CP, et al. A stepwise enteral nutrition algorithm for critically ill children helps achieve nutrient delivery goals*. Pediatr Crit Care Med (2014) 15:583-9. doi:10.1097/PCC.0000000000000179

145. Joffe A, Anton N, Lequier L, Vandermeer B, Tjosvold L, Larsen B, et al. Nutritional support for critically ill children. Cochrane Database Syst Rev (2016) 5:CD005144. doi:10.1002/14651858.CD005144.pub3

146. van den Berghe G, Wouters P, Weekers F, Verwaest C, Bruyninckx F, Schetz $\mathrm{M}$, et al. Intensive insulin therapy in critically ill patients. N Engl J Med (2001) 345:1359-67. doi:10.1056/NEJMoa011300

147. Marik PE, Preiser JC. Toward understanding tight glycemic control in the ICU: a systematic review and metaanalysis. Chest (2010) 137:544-51. doi:10.1378/chest.09-1737

148. Wiener RS, Wiener DC, Larson RJ. Benefits and risks of tight glucose control in critically ill adults: a meta-analysis. JAMA (2008) 300:933-44. doi:10.1001/ jama.300.8.933

149. Griesdale DE, de Souza RJ, van Dam RM, Heyland DK, Cook DJ, Malhotra A, et al. Intensive insulin therapy and mortality among critically ill patients: a meta-analysis including NICE-SUGAR study data. CMAJ (2009) 180:821-7. doi:10.1503/cmaj.090206

150. Wintergerst KA, Buckingham B, Gandrud L, Wong BJ, Kache S, Wilson DM. Association of hypoglycemia, hyperglycemia, and glucose variability with morbidity and death in the pediatric intensive care unit. Pediatrics (2006) 118:173-9. doi:10.1542/peds.2005-1819

151. Sertaridou E, Papaioannou V, Kolios G, Pneumatikos I. Gut failure in critical care: old school versus new school. Ann Gastroenterol (2015) 28:309-22.

152. Deitch EA. Gut lymph and lymphatics: a source of factors leading to organ injury and dysfunction. Ann N Y Acad Sci (2010) 1207(Suppl 1):E103-11. doi:10.1111/j.1749-6632.2010.05713.x

153. Clark JA, Coopersmith CM. Intestinal crosstalk: a new paradigm for understanding the gut as the "motor" of critical illness. Shock (2007) 28:384-93. doi:10.1097/shk.0b013e31805569df

154. Mittal R, Coopersmith CM. Redefining the gut as the motor of critical illness. Trends Mol Med (2014) 20:214-23. doi:10.1016/j.molmed.2013.08.004

155. Klingensmith NJ, Coopersmith CM. The gut as the motor of multiple organ dysfunction in critical illness. Crit Care Clin (2016) 32:203-12. doi:10.1016/j. ccc.2015.11.004

156. Grootjans J, Thuijls G, Verdam F, Derikx JP, Lenaerts K, Buurman WA. Noninvasive assessment of barrier integrity and function of the human gut. World J Gastrointest Surg (2010) 2:61-9. doi:10.4240/wjgs.v2.i3.61

157. Grootjans J, Lenaerts K, Derikx JP, Matthijsen RA, de Bruïne AP, van Bijnen AA, et al. Human intestinal ischemia-reperfusion-induced inflammation characterized: experiences from a new translational model. Am J Pathol (2010) 176:2283-91. doi:10.2353/ajpath.2010.091069

158. Reisinger KW, Derikx JP, Thuijls G, van der Zee DC, Brouwers HA, van Bijnen AA, et al. Noninvasive measurement of intestinal epithelial damage at time of refeeding can predict clinical outcome after necrotizing enterocolitis. Pediatr Res (2013) 73:209-13. doi:10.1038/pr.2012.160

159. Fukatsu K, Kudsk KA. Nutrition and gut immunity. Surg Clin North Am (2011) 91:755-70,vii. doi:10.1016/j.suc.2011.04.007
160. Marchiando AM, Graham WV, Turner JR. Epithelial barriers in homeostasis and disease. Annu Rev Pathol (2010) 5:119-44. doi:10.1146/annurev. pathol.4.110807.092135

161. Luo H, Guo P, Zhou Q. Role of TLR4/NF-kappaB in damage to intestinal mucosa barrier function and bacterial translocation in rats exposed to hypoxia. PLoS One (2012) 7:e46291. doi:10.1371/journal.pone. 0046291

162. Ng EW, Poon TC, Lam HS, Cheung HM, Ma TP, Chan KY, et al. Gut-associated biomarkers L-FABP, I-FABP, and TFF3 and LIT score for diagnosis of surgical necrotizing enterocolitis in preterm infants. Ann Surg (2013) 258:1111-8. doi:10.1097/SLA.0b013e318288ea96

163. Thuijls G, Derikx JP, van Wijck K, Zimmermann LJ, Degraeuwe PL, Mulder TL, et al. Non-invasive markers for early diagnosis and determination of the severity of necrotizing enterocolitis. Ann Surg (2010) 251:1174-80. doi:10.1097/SLA.0b013e3181d778c4

164. Thuijls G, Derikx JP, de Haan JJ, Grootjans J, de Bruïne A, Masclee AA, et al. Urine-based detection of intestinal tight junction loss. J Clin Gastroenterol (2010) 44:e14-9. doi:10.1097/MCG.0b013e31819f5652

165. Bailly-Botuha C, Colomb V, Thioulouse E, Berthe MC, Garcette K, Dubern $\mathrm{B}$, et al. Plasma citrulline concentration reflects enterocyte mass in children with short bowel syndrome. Pediatr Res (2009) 65:559-63. doi:10.1203/ PDR.0b013e31819986da

166. Crenn P, Messing B, Cynober L. Citrulline as a biomarker of intestinal failure due to enterocyte mass reduction. Clin Nutr (2008) 27:328-39. doi:10.1016/j. clnu.2008.02.005

167. Fitzgibbons S, Ching YA, Valim C, Zhou J, Iglesias J, Duggan C, et al. Relationship between serum citrulline levels and progression to parenteral nutrition independence in children with short bowel syndrome. J Pediatr Surg (2009) 44:928-32. doi:10.1016/j.jpedsurg.2009.01.034

168. Ioannou HP, Fotoulaki M, Pavlitou A, Efstratiou I, Augoustides-Savvopoulou P. Plasma citrulline levels in paediatric patients with celiac disease and the effect of a gluten-free diet. Eur J Gastroenterol Hepatol (2011) 23:245-9. doi:10.1097/MEG.0b013e3283438ad7

169. Piton G, Manzon C, Monnet E, Cypriani B, Barbot O, Navellou JC, et al. Plasma citrulline kinetics and prognostic value in critically ill patients. Intensive Care Med (2010) 36:702-6. doi:10.1007/s00134-010-1751-6

170. Diamanti A, Panetta F, Gandullia P, Morini F, Noto C, Torre G, et al. Plasma citrulline as marker of bowel adaptation in children with short bowel syndrome. Langenbecks Arch Surg (2011) 396:1041-6. doi:10.1007/ s00423-011-0813-8

171. Merlin E, Minet-Quinard R, Pereira B, Rochette E, Auvrignon A, Oudot C, et al. Non-invasive biological quantification of acute gastrointestinal graft-versus-host disease in children by plasma citrulline. Pediatr Transplant (2013) 17:683-7. doi:10.1111/petr.12128

172. Hensel KO, Boland V, Postberg J, Zilbauer M, Heuschkel R, Vogel S, et al. Differential expression of mucosal trefoil factors and mucins in pediatric inflammatory bowel diseases. Sci Rep (2014) 4:7343. doi:10.1038/ srep07343

173. Caporaso JG, Kuczynski J, Stombaugh J, Bittinger K, Bushman FD, Costello EK, et al. QIIME allows analysis of high-throughput community sequencing data. Nat Methods (2010) 7:335-6. doi:10.1038/nmeth.f.303

174. Cummings JH, Macfarlane GT. Role of intestinal bacteria in nutrient metabolism. JPEN J Parenter Enteral Nutr (1997) 21:357-65. doi:10.1177/0148607 197021006357

175. Yatsunenko T, Rey FE, Manary MJ, Trehan I, Dominguez-Bello MG, Contreras $\mathrm{M}$, et al. Human gut microbiome viewed across age and geography. Nature (2012) 486:222-7. doi:10.1038/nature11053

176. Cox LM, Yamanishi S, Sohn J, Alekseyenko AV, Leung JM, Cho I, et al. Altering the intestinal microbiota during a critical developmental window has lasting metabolic consequences. Cell (2014) 158:705-21. doi:10.1016/j. cell.2014.05.052

177. Cho I, Yamanishi S, Cox L, Methé BA, Zavadil J, Li K, et al. Antibiotics in early life alter the murine colonic microbiome and adiposity. Nature (2012) 488:621-6. doi:10.1038/nature11400

178. Tanaka S, Kobayashi T, Songjinda P, Tateyama A, Tsubouchi M, Kiyohara C et al. Influence of antibiotic exposure in the early postnatal period on the development of intestinal microbiota. FEMS Immunol Med Microbiol (2009) 56:80-7. doi:10.1111/j.1574-695X.2009.00553.x 
179. Sjögren YM, Tomicic S, Lundberg A, Böttcher MF, Björkstén B, SverremarkEkström E, et al. Influence of early gut microbiota on the maturation of childhood mucosal and systemic immune responses. Clin Exp Allergy (2009) 39:1842-51. doi:10.1111/j.1365-2222.2009.03326.x

180. Samuelson DR, Welsh DA, Shellito JE. Regulation of lung immunity and host defense by the intestinal microbiota. Front Microbiol (2015) 6:1085. doi:10.3389/fmicb.2015.01085

181. Carmody RN, Gerber GK, Luevano JM Jr, Gatti DM, Somes L, Svenson KL, et al. Diet dominates host genotype in shaping the murine gut microbiota. Cell Host Microbe (2015) 17:72-84. doi:10.1016/j.chom.2014.11.010

182. Briassoulis G, Filippou O, Kanariou M, Hatzis T. Comparative effects of early randomized immune or non-immune-enhancing enteral nutrition on cytokine production in children with septic shock. Intensive Care Med (2005) 31:851-8. doi:10.1007/s00134-005-2631-3

183. Heyland DK, Dhaliwal R, Day AG, Muscedere J, Drover J, Suchner U, et al. REducing Deaths due to OXidative Stress (The REDOXS Study): rationale and study design for a randomized trial of glutamine and antioxidant supplementation in critically-ill patients. Proc Nutr Soc (2006) 65:250-63. doi:10.1079/PNS2006505

184. Andrews PJ, Avenell A, Noble DW, Campbell MK, Battison CG, Croal BL, et al. Randomised trial of glutamine and selenium supplemented parenteral nutrition for critically ill patients. Protocol Version 9, 19 February 2007 known as SIGNET (Scottish Intensive care Glutamine or seleNium Evaluative Trial). Trials (2007) 8:25. doi:10.1186/1745-6215-8-25

185. Allingstrup $M$, Afshari A. Selenium supplementation for critically ill adults. Cochrane Database Syst Rev (2015) 7:CD003703. doi:10.1002/14651858. CD003703.pub3

186. Barbosa E, Moreira EA, Goes JE, Faintuch J. Pilot study with a glutamine-supplemented enteral formula in critically ill infants. Rev Hosp Clin Fac Med Sao Paulo (1999) 54:21-4. doi:10.1590/S0041-87811999000100005

187. Brodska H, Valenta J, Malickova K, Kohout P, Kazda A, Drabek T. Biomarkers in critically ill patients with systemic inflammatory response syndrome or sepsis supplemented with high-dose selenium. J Trace Elem Med Biol (2015) 31:25-32. doi:10.1016/j.jtemb.2015.02.005

188. Heyland DK, Dhaliwal R, Drover JW, Gramlich L, Dodek P, Canadian Critical Care Clinical Practice Guidelines Committee. Canadian clinical practice guidelines for nutrition support in mechanically ventilated, critically ill adult patients. JPEN J Parenter Enteral Nutr (2003) 27:355-73. doi:10.117 7/0148607103027005355

189. Mayes T, Gottschlich MM, Kagan RJ. An evaluation of the safety and efficacy of an anti-inflammatory, pulmonary enteral formula in the treatment of pediatric burn patients with respiratory failure. J Burn Care Res (2008) 29:82-8. doi:10.1097/BCR.0b013e31815f594e

190. Tao KM, Li XQ, Yang LQ, Yu WF, Lu ZJ, Sun YM, et al. Glutamine supplementation for critically ill adults. Cochrane Database Syst Rev (2014) 9:CD010050. doi:10.1002/14651858.CD010050.pub2

191. Briassoulis G, Filippou O, Hatzi E, Papassotiriou I, Hatzis T. Early enteral administration of immunonutrition in critically ill children: results of a blinded randomized controlled clinical trial. Nutrition (2005) 21:799-807. doi:10.1016/j.nut.2004.12.006

192. Garcia de Acilu M, Leal S, Caralt B, Roca O, Sabater J, Masclans JR. The role of omega-3 polyunsaturated fatty acids in the treatment of patients with acute respiratory distress syndrome: a clinical review. Biomed Res Int (2015) 2015:653750. doi:10.1155/2015/653750

193. Hall TC, Bilku DK, Al-Leswas D, Neal CP, Horst C, Cooke J, et al. A randomized controlled trial investigating the effects of parenteral fish oil on survival outcomes in critically ill patients with sepsis: a pilot study. JPEN J Parenter Enteral Nutr (2015) 39:301-12. doi:10.1177/0148607113518945
194. Hecker M, Linder T, Ott J, Walmrath HD, Lohmeyer J, Vadász I, et al. Immunomodulation by lipid emulsions in pulmonary inflammation: a randomized controlled trial. Crit Care (2015) 19:226. doi:10.1186/ s13054-015-0933-6

195. Li C, Bo L, Liu W, Lu X, Jin F. Enteral immunomodulatory diet (omega-3 fatty acid, gamma-linolenic acid and antioxidant supplementation) for acute lung injury and acute respiratory distress syndrome: an updated systematic review and meta-analysis. Nutrients (2015) 7:5572-85. doi:10.3390/nu7075239

196. Li X, Zhang X, Yang E, Zhang N, Cao S, Zhou Y. Fish oil-supplemented parenteral nutrition could alleviate acute lung injury, modulate immunity, and reduce inflammation in rats with abdominal sepsis. Nutr Res (2015) 35:784-91. doi:10.1016/j.nutres.2015.06.008

197. Manzanares W, Langlois PL, Dhaliwal R, Lemieux M, Heyland DK. Intravenous fish oil lipid emulsions in critically ill patients: an updated systematic review and meta-analysis. Crit Care (2015) 19:167. doi:10.1186/ s13054-015-0888-7

198. Serhan CN, Petasis NA. Resolvins and protectins in inflammation resolution. Chem Rev (2011) 111:5922-43. doi:10.1021/cr100396c

199. Onwuneme C, Martin F, McCarthy R, Carroll A, Segurado R, Murphy J, et al. The association of vitamin $\mathrm{D}$ status with acute respiratory morbidity in preterm infants. J Pediatr (2015) 166:1175.e-80.e. doi:10.1016/j.jpeds. 2015.01.055

200. Dancer RC, Parekh D, Lax S, D'Souza V, Zheng S, Bassford CR, et al. Vitamin D deficiency contributes directly to the acute respiratory distress syndrome (ARDS). Thorax (2015) 70:617-24. doi:10.1136/thoraxjnl-2014206680

201. Thickett DR, Moromizato T, Litonjua AA, Amrein K, Quraishi SA, LeeSarwar KA, et al. Association between prehospital vitamin D status and incident acute respiratory failure in critically ill patients: a retrospective cohort study. BMJ Open Respir Res (2015) 2:e000074. doi:10.1136/bmjresp2014-000074

202. Parekh D, Thickett DR, Turner AM. Vitamin D deficiency and acute lung injury. Inflamm Allergy Drug Targets (2013) 12:253-61. doi:10.2174/18715 281113129990049

203. Heulens N, Korf H, Cielen N, De Smidt E, Maes K, Gysemans C, et al. Vitamin D deficiency exacerbates COPD-like characteristics in the lungs of cigarette smoke-exposed mice. Respir Res (2015) 16:110. doi:10.1186/ s12931-015-0271-X

204. Foong RE, Bosco A, Jones AC, Gout A, Gorman S, Hart PH, et al. The effects of in utero vitamin D deficiency on airway smooth muscle mass and lung function. Am J Respir Cell Mol Biol (2015) 53:664-75. doi:10.1165/ rcmb.2014-0356OC

205. Nouari W, Ysmail-Dahlouk L, Aribi M. Vitamin D3 enhances bactericidal activity of macrophage against Pseudomonas aeruginosa. Int Immunopharmacol (2016) 30:94-101. doi:10.1016/j.intimp.2015.11.033

Conflict of Interest Statement: Dr. KT has received an investigator initiated grant from the Baxter Corporation in support of research to perform a clinical trial of early versus later $\mathrm{PN}$ in mechanically ventilated children. Funds provided by Baxter do not support her effort on the project, but provide project funds. BW declares no conflict of interest.

Copyright (C) 2016 Wilson and Typpo. This is an open-access article distributed under the terms of the Creative Commons Attribution License (CC BY). The use, distribution or reproduction in other forums is permitted, provided the original author(s) or licensor are credited and that the original publication in this journal is cited, in accordance with accepted academic practice. No use, distribution or reproduction is permitted which does not comply with these terms. 